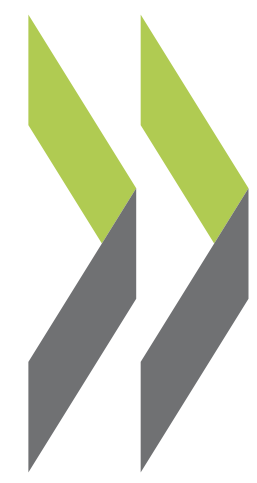

OECD Economics Department Working Papers No. 1689

Christophe André,

Keeping regional inequality Jinwoan Beom, in check in Sweden Mathilde Pak, Axel Purwin 


\section{ECONOMICS DEPARTMENT}

\section{KEEPING REGIONAL INEQUALITY IN CHECK IN SWEDEN}

\section{ECONOMICS DEPARTMENT WORKING PAPERS No. 1689}

By Christophe André, Jinwoan Beom, Mathilde Pak and Axel Purwin

OECD Working Papers should not be reported as representing the official views of the OECD or of its member countries. The opinions expressed and arguments employed are those of the author(s).

Authorised for publication by Alvaro Pereira, Director, Country Studies Branch, Economics Department.

All Economics Department Working Papers are available at www.oecd.org/eco/workingpapers. 
OECD Working Papers should not be reported as representing the official views of the OECD or of its member countries. The opinions expressed and arguments employed are those of the author(s).

Working Papers describe preliminary results or research in progress by the author(s) and are published to stimulate discussion on a broad range of issues on which the OECD works.

Comments on Working Papers are welcomed, and may be sent to the Economics Department, OECD, 2 rue André-Pascal, 75775 Paris Cedex 16, France, or by e-mail to PubRights@oecd.org.

All Economics Department Working Papers are available at www.oecd.org/eco/workingpapers.

This document and any map included herein are without prejudice to the status of or sovereignty over any territory, to the delimitation of international frontiers and boundaries and to the name of any territory, city or area.

The statistical data for Israel are supplied by and under the responsibility of the relevant Israeli authorities. The use of such data by the OECD is without prejudice to the status of the Golan Heights, East Jerusalem and Israeli settlements in the West Bank under the terms of international law.

C OECD (2021)

You can copy, download or print OECD content for your own use, and you can include excerpts from OECD publications, databases and multimedia products in your own documents, presentations, blogs, websites and teaching materials, provided that suitable acknowledgment of OECD as source and copyright owner is given. All requests for commercial use and translation rights should be submitted to Pubrights@oecd.org 


\section{ABSTRACT/RÉSUMÉ}

\section{Keeping regional inequality in check in Sweden}

Regional inequality is low in Sweden compared to most other OECD countries, but has been rising over the past decades, fuelling discontent in parts of the country, whose inhabitants feel left behind. The younger population is increasingly concentrated in the largest cities, which also enjoy the highest productivity growth. Demographic trends exacerbate the difficulty in providing equal public services across the country. Healthy public finances are allowing the government to increase its support to municipalities and regions to adjust to demographic developments and local operating conditions. Beyond this effort, keeping regional inequality in check will require upgrading the sub-national government fiscal framework, enhancing public service efficiency, especially through digitalisation, and promoting regional convergence further, especially by strengthening the role of universities in regional knowledge and innovation networks.

This Working Paper relates to the 2021 OECD Economic Survey of Sweden (http://www.oecd.org/economy/sweden-economic-snapshot/)

JEL Classification: H71, H72, P48, R11, R50.

Keywords: Sweden; Regional inequality; State and local taxation, subsidies, and revenue; State and local budget and expenditures; Regional Studies; Regional economic activity; Regional government analysis.

$\star * * * * * * * * * * * *$

\section{Maîtriser les inégalités régionales en Suède}

Les inégalités régionales sont faibles en Suède par rapport à la plupart des autres pays de l'OCDE, mais elles ont augmenté au cours des dernières décennies, alimentant le mécontentement dans certaines parties du pays, dont les habitants se sentent laissés pour compte. La population la plus jeune est de plus en plus concentrée dans les principales agglomérations, qui bénéficient également de la plus forte croissance de la productivité. Les tendances démographiques exacerbent la difficulté à assurer un accès égal aux services publics à travers le pays. Des finances publiques saines permettent au gouvernement d'accroître son soutien aux communes et aux régions pour s'adapter aux évolutions démographiques et aux conditions locales. Au-delà de cet effort, la maîtrise des inégalités régionales nécessitera de moderniser le cadre budgétaire des administrations infranationales, d'améliorer l'efficacité des services publics, notamment grâce à la numérisation, et de promouvoir davantage la convergence régionale, notamment en renforçant le rôle des universités dans les réseaux régionaux de connaissances et d'innovation.

Ce Document de travail a trait à l'Étude économique de l'OCDE de la Suède, 2020 (http://www.oecd.org/fr/economie/suede-en-un-coup-d-oeil/).

JEL Classification : H71, H72, P48, R11, R50.

Mots clés : Suède, Inégalité régionale; Fiscalité, subventions et recettes de l'État et des collectivités locales ; Budget et dépenses de l'État et des collectivités locales ; Études régionales ; Activité économique régionale ; Analyse du gouvernement régional. 


\section{Table of contents}

Keeping regional inequality in check in Sweden $\quad 5$

$\begin{array}{lr}\text { Regional inequalities are increasing albeit from a low level } & 7\end{array}$

Sweden is among the most decentralised OECD countries $\quad 10$

The equalisation system compensates most differences in tax capacity and costs 13

Regions and municipalities face diverse challenges $\quad 17$

The central government is increasing its support to municipalities and regions 21

Digitalisation offers opportunities to enhance public service delivery 23

Promoting regional growth and employment is essential 26

Recommendations to contain the rise in regional inequality 33

$\begin{array}{ll}\text { References } & 34\end{array}$

\section{FIGURES}

Figure 1. GDP growth has varied considerably across regions $\quad 8$

Figure 2. Real output per capita and population have diverged $\quad 8$

Figure 3. Regional disparity remains relatively low 9

Figure 4. Well-being varies across regions $\quad 10$

Figure 5. Sub-national governments make up a large part of public consumption and investment 11

Figure 6. Sub-national governments account for a large share of public revenue and spending 12

Figure 7. The share of property tax revenue is smaller than in the other Nordics $\quad 12$

Figure 8. Equalising transfers are slightly above peer countries' average $\quad 13$

Figure 9. Revenue equalisation is predominant in Sweden $\quad 14$

Figure 10. The Swedish cost equalisation system is relatively complex 14

Figure 11. A large share of the population is concentrated in the three main cities 17

$\begin{array}{ll}\text { Figure 12. Dependency ratios are increasing and diverging across regions } & 18\end{array}$

Figure 13. Stockholm is one of the most innovative regions in Europe 20

Figure 14. Contributions to municipal spending and revenue $\quad 22$

Figure 15. Sweden is among the world's leading countries in e-government 24

Figure 16. Access to high-speed broadband remains limited in rural areas 24

Figure 17. Productivity varies significantly across regions $\quad 27$

Figure 18. Persistence of inequality in productivity levels within countries $\quad 27$

$\begin{array}{lr}\text { Figure 19. Job creation in capital regions } & 28\end{array}$

Figure 20. Telework possibilities are uneven across regions $\quad 32$

\section{TABLES}

Table 1. Panel regressions for labour productivity 


\title{
Keeping regional inequality in check in Sweden
}

\author{
By Christophe André, Jinwoan Beom, Mathilde Pak and Axel Purwin ${ }^{1}$
}

Regional inequality has been rising since the early 1980 s and, while remaining low by international standards, risks weakening economic opportunities, well-being and social cohesion. As in many other OECD countries, widening regional inequality has increasingly fuelled discontent among citizens feeling left behind (OECD, 2017a). The main urban areas, and particularly Stockholm, are enjoying the strongest growth in both population and productivity. While the move of younger and better educated individuals to big cities is not new, it no longer coincides with productivity convergence, due to strong agglomeration effects in an increasingly knowledge-based economy. Regional divergence is likely to continue, even though the COVID-19 pandemic may slow migration to cities and the acceleration in digitalisation could weaken agglomeration effects and mitigate the disadvantage of remoteness. Some Northern regions have also enjoyed strong output growth over recent years despite demographic headwinds, largely thanks to developments in mining and renewable energy.

Regional and municipal finances are coming under pressure. Providing equal public services to citizens across the country is becoming increasingly challenging (Swedish government, 2019a, 2020a). In addition, the share of both young people and the elderly is increasing nationwide, pushing up demand for education, health and other social services across the country, but with regional differences. Infrastructure is ageing, imposing renewal investments.

Sweden is one of the most decentralised OECD countries, with regions and municipalities receiving a significant share of fiscal revenue and being responsible for most welfare services. Steady economic growth generated strong tax revenue until 2017, but weakening activity has subsequently reduced income growth and pushed up expenditure, even before the COVID-19 crisis hit. The central government has responded by increasing grants to sub-national governments (regions and municipalities) and more than compensated for COVID-19-related costs in 2020, which has markedly improved the financial position of sub-national governments. Nevertheless, many of them will face strong headwinds going forward. Beyond financial constraints, many sub-national governments face shortages of skilled workers, which increasingly hampers the provision of high-quality public services. While additional central government funding, enhanced fiscal equalisation and efficiency gains can help mitigate these problems, policies should also

\footnotetext{
${ }^{1}$ The authors are from the OECD Economics Department (ECO). They would like to thank Oliver Denk, Vincent Koen, Isabell Koske, Alvaro Pereira (ECO), Bert Brys (Centre for Tax Policy and Administration), Sebastian Königs (Directorate for Employment, Labour and Social Affairs) and Kristoffer Lundberg for useful comments and suggestions. The paper has also benefitted from comments by Swedish officials and by members of the OECD Economic and Development Review Committee. Special thanks go to Natia Mosiashvili for statistical assistance and to Sisse Nielsen for editorial assistance.
} 


\section{6 | ECO/WKP(2021)40}

aim at boosting the growth potential of all regions to foster job opportunities, inclusiveness and well-being throughout the country.

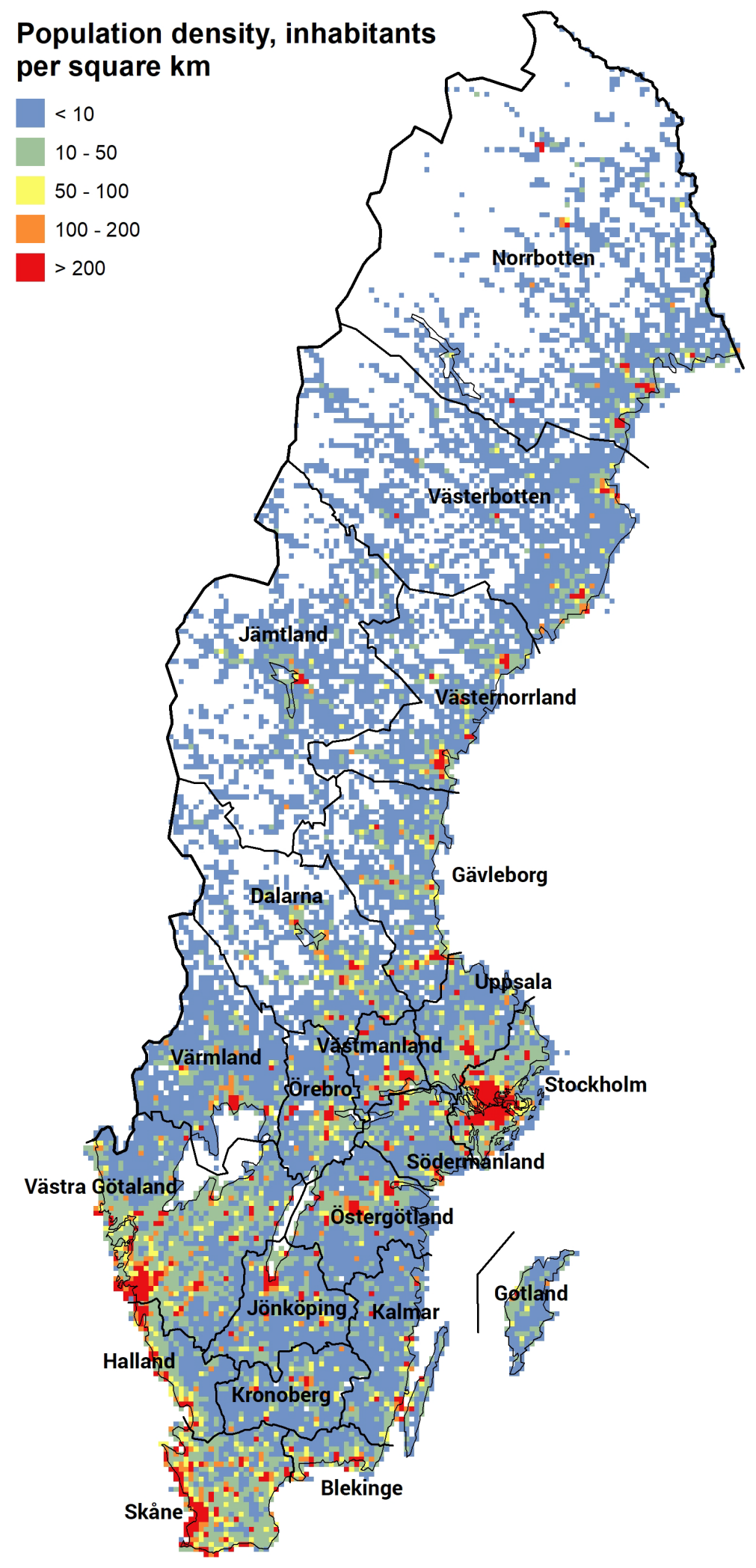

Source: Statistics Sweden. 
In March 2021, the government unveiled its 2021-2030 National strategy for sustainable regional development throughout the country (Swedish Government, 2021). The strategy aims at tackling environmental, climate, demographic and inequality challenges, while reinforcing competitiveness throughout the country, by enhancing capacities for regional and local development action, strengthening multi-level governance and coordination between government institutions, regions and other stakeholders, and strengthening policy assessment through research and evaluation. The strategy identifies four strategic areas: equal opportunities for housing, work and welfare; competence supply and development; innovation, renewal and entrepreneurship; accessibility through digital communication and transport systems.

This paper is structured as follows. The first section outlines recent developments in regional inequality. The second maps the resources and responsibilities of different levels of government. The third section describes the fiscal equalisation system. The fourth explores the challenges faced by various types of regions and municipalities. The fifth shows how the central government is supporting municipalities and regions. The sixth investigates opportunities offered by digitalisation to enhance public service delivery. The last section looks at ways to promote regional growth and employment.

\section{Regional inequalities are increasing albeit from a low level}

Real gross regional domestic product (GRDP) growth has varied widely across Swedish regions over the period $2000-18$, ranging from more than $70 \%$ in Stockholm to less than $15 \%$ in Kalmar (Figure 1). This stems mainly from differences in productivity and population growth, although the evolutions in the age structure of the population and the employment rate also play a role. GDP per capita has diverged across regions, as illustrated by the positive correlation between GRDP per capita levels in 2000 and subsequent growth (Figure 2, Panel A). The correlation overwhelmingly reflects outstanding performances in the regions of Stockholm and Gothenburg (Västra Götaland). Despite the divergence over the past decades, disparities in GRDP per capita between the Swedish regions remain lower than among comparable regions in other OECD countries, in half of which regional inequality has also increased since 2008 (Figure 3). While there was some convergence between EU28 regions since 1997, it slowed after the 2008 global financial crisis. Furthermore, convergence was exclusively driven by between-country convergence, while regional dispersion within countries increased somewhat, with capital regions in many cases pulling away from other regions (Bisciari et al., 2020). In Sweden, an extensive welfare model, coordinated wage bargaining, as well as a clear objective of territorial equity in national policies, contribute to low regional inequality.

Population growth is also diverging (Figure 2, Panel B). Hence, both population inflows and GRDP per capita are lifting leading regions' output. This combination, which dates back to the early 1980s, is unique in Swedish history (Enflo, 2016). During the period between the Second World War and 1980, a reallocation of labour across regions and sectors strongly contributed to convergence in GRDP per capita (Enflo and Roses, 2015). The new pattern reflects agglomeration effects in an increasingly knowledgebased economy. Large agglomerations allow economies of scale, better labour market matching among a larger pool of workers and knowledge spillovers. International studies suggest that a doubling in population size raises the productivity level of a city by $2 \%$ to $5 \%$ (OECD, 2015a). Contrary to many other OECD countries (Gbohoui et al., 2019), the internal migration rate in Sweden has increased slightly since 2000, and especially since 2012 , which suggests relatively strong labour market mobility. This is consistent with micro-data evidence pointing to more efficient reallocation of labour in Sweden than in most other OECD countries (Andrews and Cingano, 2014). 


\section{Figure 1. GDP growth has varied considerably across regions}

Contributions to real gross regional domestic product percentage change, 2000-18, TL3 regions

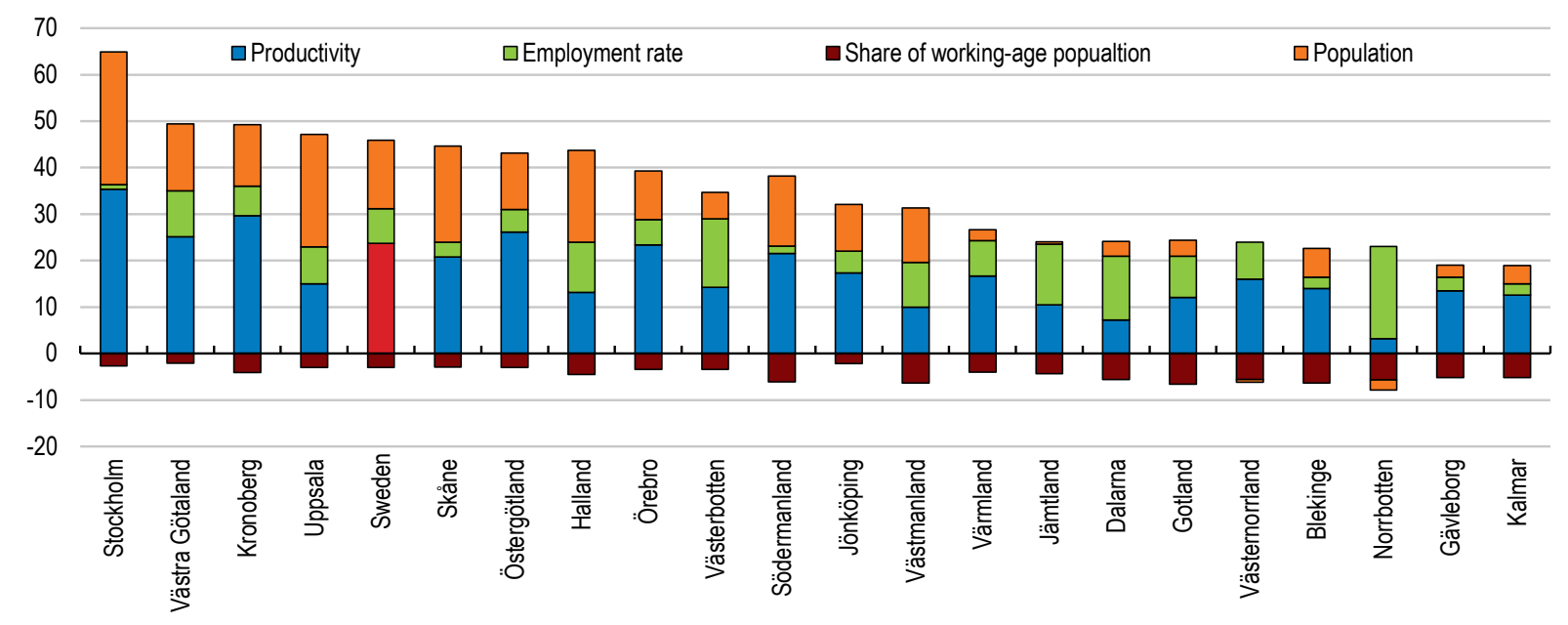

Note: Data are adjusted for changes in the perimeter of some regions during the period. This has a minor impact on the results. Source: Authors' calculations based on Statistics Sweden Regional Accounts (accessed on 8 December 2020).

Sparsely populated regions have experienced slow population growth since 2000 , even negative in two cases, as well as generally low productivity growth. Even though the fall in the ratio of working-age to total population is a national phenomenon, it is more acute in sparsely populated regions. Some of them, particularly in the North, have been able to compensate the impact of ageing on labour supply by a significant increase in the employment rate, but the situation is uneven across regions.

\section{TL3 regions}

A. Real Gross regional domestic product per capita

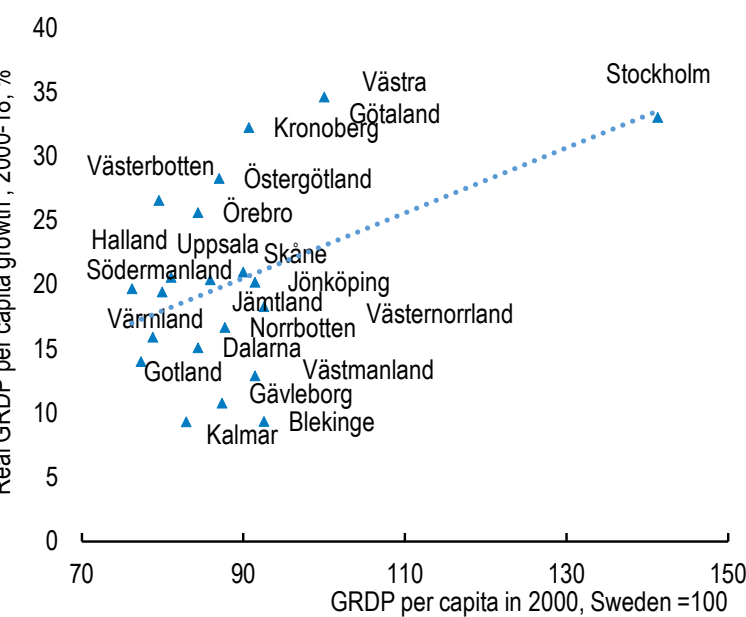

\section{B. Population}

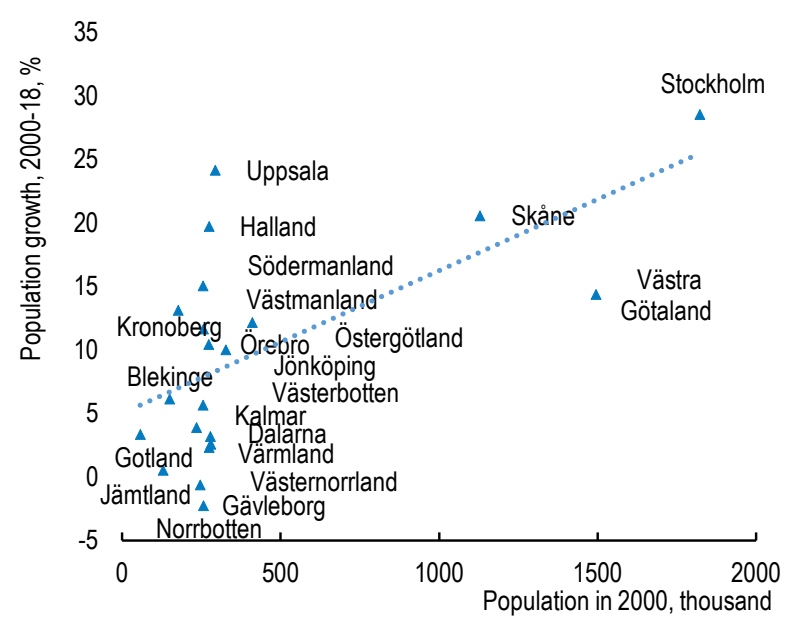

Note: Data are adjusted for changes in the perimeter of some regions during the period. This has a minor impact on the results.

Source: Authors' calculations based on Statistics Sweden Regional Accounts (accessed on 8 December 2020).

Income is more equally distributed than GDP per capita, thanks to coordinated wage bargaining, which results in a relatively compressed wage distribution, and to taxes and transfers. Still, in 2018, equivalised disposable income (income per household adjusted for family composition) is about $17 \%$ above the national average in Stockholm, $4 \%$ above average in Gothenburg and below average in the rest of the country, with the lowest level in predominantly rural remote areas, at about $14 \%$ below the national average. Differences in living costs, for which data are not available, may mitigate these differences 
somewhat, even though taking housing costs into account does not alter the picture significantly (Swedish Government, 2019a). Welfare services contribute to narrowing regional inequality, as rural households tend to use more of them than their urban counterparts due to demographic differences. Although this contribution is difficult to quantify, estimates suggest that it could reduce the gap between Stockholm and rural remote areas by more than ten percentage points (Swedish Government, 2019a).

Figure 3. Regional disparity remains relatively low

Regional disparity in GDP per capita, TL3 regions

Ratio of RGDP in the top 20\% richest regions over that in the bottom 20\% poorest regions

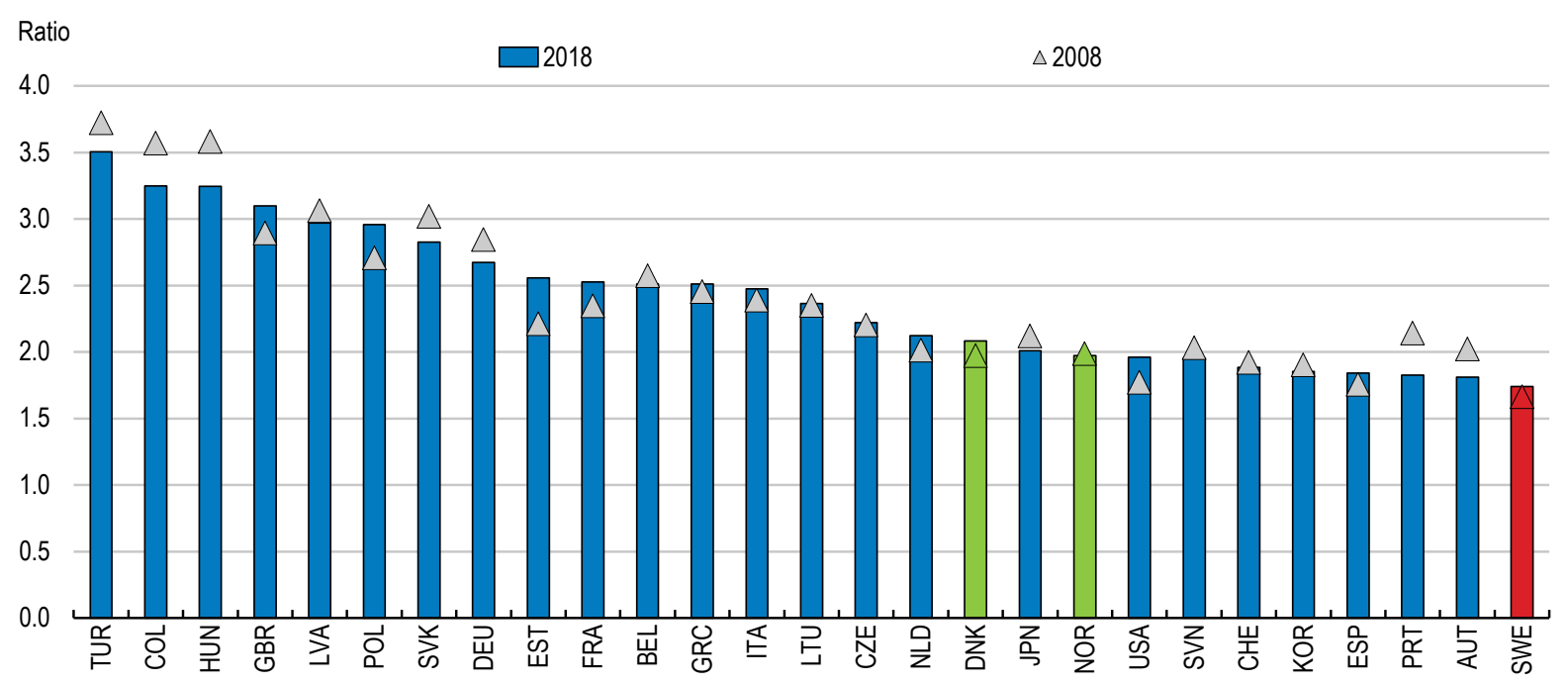

Note: The GDP per capita of the top and bottom $20 \%$ regions are defined as those with the highest/lowest GDP per capita until the equivalent of $20 \%$ of national population is reached. Based on GDP per capita values expressed at 2015 constant prices, using OECD country deflators and converted into constant USD purchasing power parities (PPPs), 2015 reference year. 2008-2018, except last available year for COL, LVA, LTU, NZL and CHE: 2017; JPN: 2016.

Source: OECD Regional Statistics database.

Regional inequality is also evident in several other dimensions of well-being, despite generally high scores, with many Swedish regions among the top $20 \%$ of OECD regions in several dimensions and no region among the bottom $20 \%$ in any dimension (Figure 4). Civic engagement, access to services, life satisfaction and the quality of the environment are high throughout the country. Nevertheless, large regional differences appear in other areas, with some weak spots, including housing shortages in Stockholm, job scarcity and safety issues in South Sweden and a perceived lack of social network support in Upper Norrland. This illustrates different challenges across the country, as South Sweden struggles with social issues and gang violence (Sturrup et al., 2019), while Northernmost regions are suffering from declining and ageing populations. 
Figure 4. Well-being varies across regions

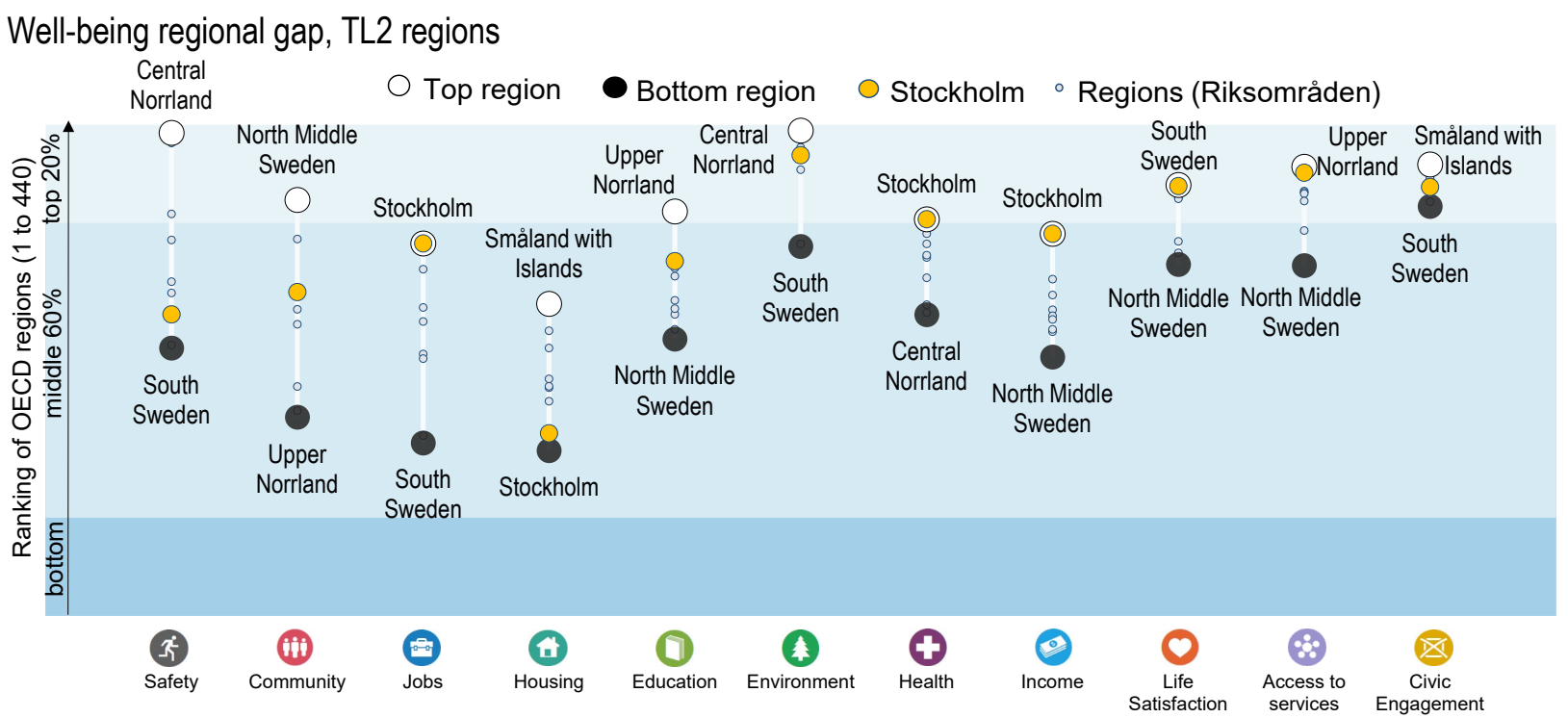

Note: Relative ranking of the regions with the best and worst outcomes in the 11 well-being dimensions, with respect to all 440 OECD regions. The eleven dimensions are ranked according to the size of regional disparities in the country. This chart refers to large regions (TL2) rather than the small regions generally referred to in this paper due to data availability. Upper Norrland includes Norrbotten and Västerbotten; Central Norrland includes Jämtland and Västernorrland; North Middle Sweden includes Dalarna, Gävleborg and Värmland; Småland with Islands includes Gotland, Jönköping, Kalmar and Kronoberg; South Sweden includes Blekinge and Skåne.

Source: OECD Regions and Cities at a Glance 2020.

Swedish sub-national governments, like their other Nordic counterparts, enjoy extensive responsibilities and relatively high autonomy, even though strict national regulations and standard requirements impose significant constraints in some areas. Fiscal decentralisation in OECD countries is generally associated with lower disparities in regional GDP per capita, and a more rapid pace of convergence (Blöchliger et al., 2016).

Health care is the main responsibility of regions, although they also have a significant role in transport and regional development. Municipalities are responsible for providing a wide range of welfare services (Box 1). They account for nearly half of general government final consumption, with the other half almost equally divided between regions and central government. In total, sub-national governments account for more than $70 \%$ of general government final consumption, the highest share in the OECD, and more than half of general government investment, the fifth highest share in the OECD (Figure 5). Altogether, sub-national government spending represents about half of public spending, the second highest share in the OECD after Denmark (Figure 6, Panel A), and nearly a third of public revenue, the highest share in the OECD (Panel B). Municipalities and regions have discretion on tax rates, which is an important dimension of fiscal autonomy (Dougherty et al., 2019; Forman et al., 2020).

\section{Box 1. Sub-national government responsibilities in Sweden}

Sweden has three levels of government, central, regional (21 regions) and local (290 municipalities). Municipal and regional councils are directly elected by citizens and other entitled residents. The population of regions ranges from barely 58000 (Gotlands kommun) to about 2.3 million (Stockholm) and for municipalities from less than 2500 (Bjurholm) to close to one million (Stockholm). 
Regions are mainly responsible for health care, transport and regional development, although they can also take responsibilities for culture, training and tourism. In 2019, health care accounted for about $88 \%$ of regional expenditure and transport and infrastructure for nearly $10 \%$. Personnel costs represented around $45 \%$ of spending and outsourcing of services $17 \%$. Taxes and charges accounted for nearly $73 \%$ of revenue and general and earmarked grants from central government for respectively $8 \%$ and $14 \%$ (including grants for high-cost drugs).

Municipalities are responsible for providing a wide range of services, including pre-school, primary and secondary education, social services, elderly care, environmental and health protection, land-use planning and housing. They can also be involved in leisure and culture, energy and employment services, as well as business development. In 2019 , on average more than $40 \%$ of expenses went to education and training, $18 \%$ to elderly care, $11 \%$ to support for people with disabilities and $7 \%$ to infrastructure and protection. Personnel expenses accounted for about $55 \%$ of costs and outsourcing of services for $18 \%$. Taxes and charges accounted for more than $70 \%$ of revenue and general and earmarked grants from central government for respectively $14 \%$ and $6 \%$.

Source: Swedish Association of Local Authorities and Regions.

Figure 5. Sub-national governments make up a large part of public consumption and investment Sub-national government consumption and investment as a share of total public consumption and investment, 2018 or latest

A. Final consumption expenditure

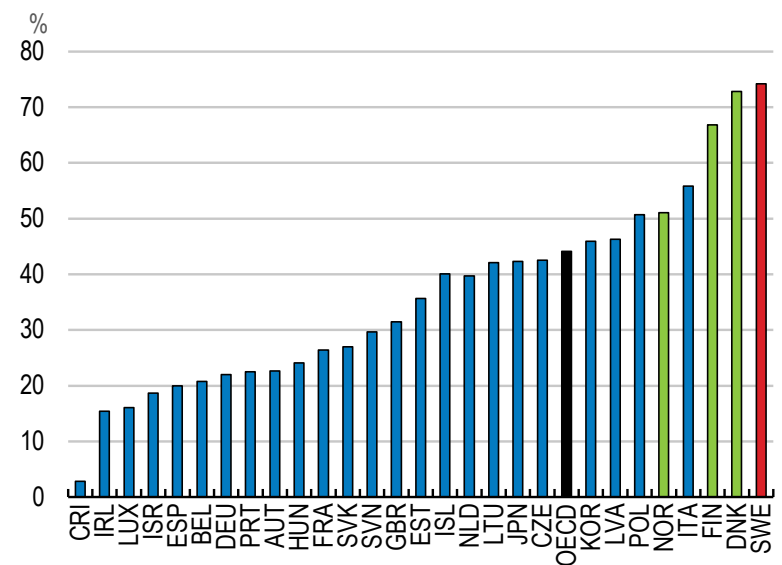

B. Gross fixed capital formation

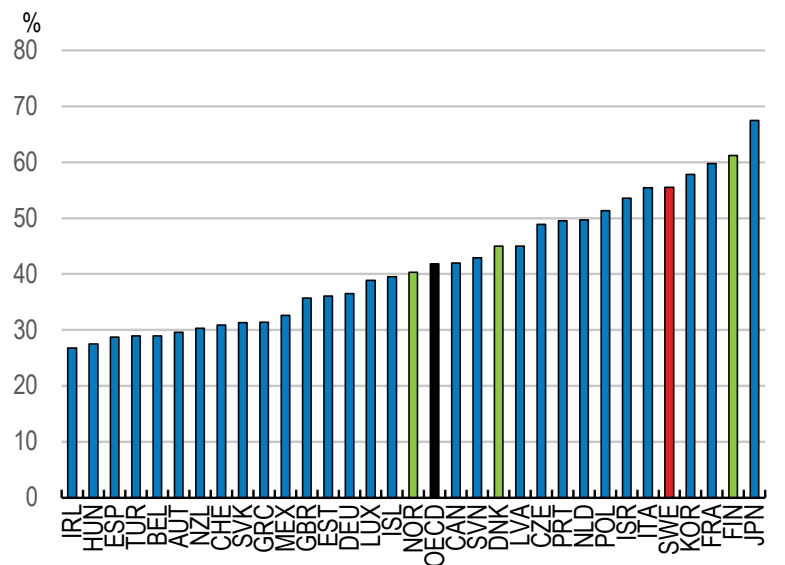

Note: In Panel A, data for Costa Rica and Luxembourg refer to 2017 values, and data for the Netherlands refers to 2019 values. In Panel B, data for New Zealand and Turkey refer to 2017 values. Data for the OECD refer to an unweighted average of the countries for which the data are available.

Source: OECD National Accounts database.

Personal income tax accounts for the largest part of sub-national government revenue, a common feature of highly decentralised countries (Forman et al., 2020). As the tax mix is strongly related to the degree of decentralisation, comparing the tax mix at a sub-central level is only relevant for relatively similar countries. The main source of sub-national government revenue in the other Nordic countries is also personal income tax. However, in the other Nordic countries, a higher share of revenue comes from property taxes (Figure 7). Recurrent property taxes are among the least detrimental to growth (Arnold et al., 2011; Cournède et al., 2018). Sweden combines generous mortgage interest deductibility with a recurrent tax on residential immovable property, which is capped at a relatively low level, making it regressive. The marginal effective tax rate for owner-occupied, debt-financed housing investments is the third lowest in the 27 OECD countries for which data are available, after the Netherlands and Denmark (Brys et al., 2021). The OECD Economic Survey of Sweden 2019 recommended reforming the recurrent tax on immovable property to 
better align tax charges with property values and phasing out the deductibility of mortgage interest rate payments. In addition to making the tax system more neutral with respect to owning or renting a dwelling, with a likely positive impact on housing market and macroeconomic stability, this could generate additional revenue for municipalities.

Figure 6. Sub-national governments account for a large share of public revenue and spending Sub-national government revenue and spending in 2018 as a share of total public revenue and spending ${ }^{1}$
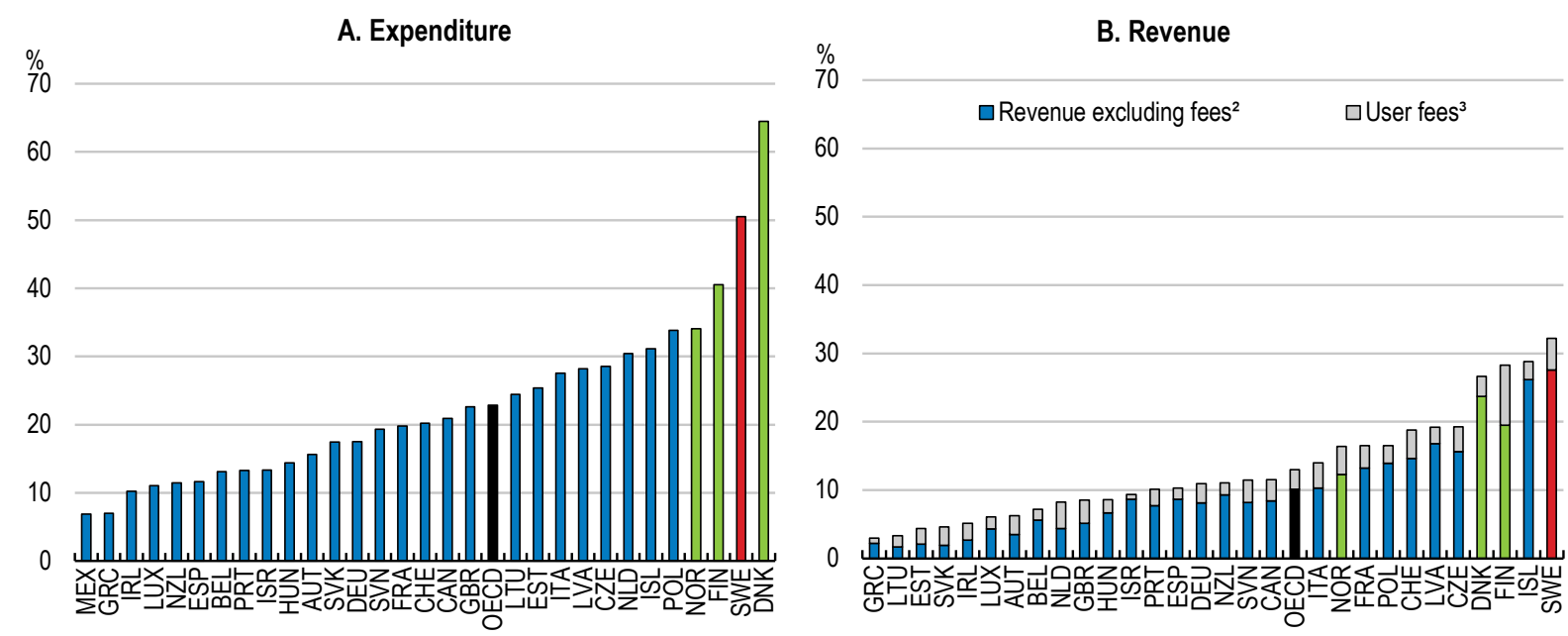

1. Data for New Zealand refer to 2017. Data for the OECD refer to an unweighted average.

2. Excludes grants and subsidies.

3. Individual payments to public service providers, including collective and private co-payments through insurance schemes, in return for services provided.

Source: OECD Fiscal Decentralisation database.

Figure 7. The share of property tax revenue is smaller than in the other Nordics

Breakdown of local government tax revenue as a share of total local tax revenue, 2018

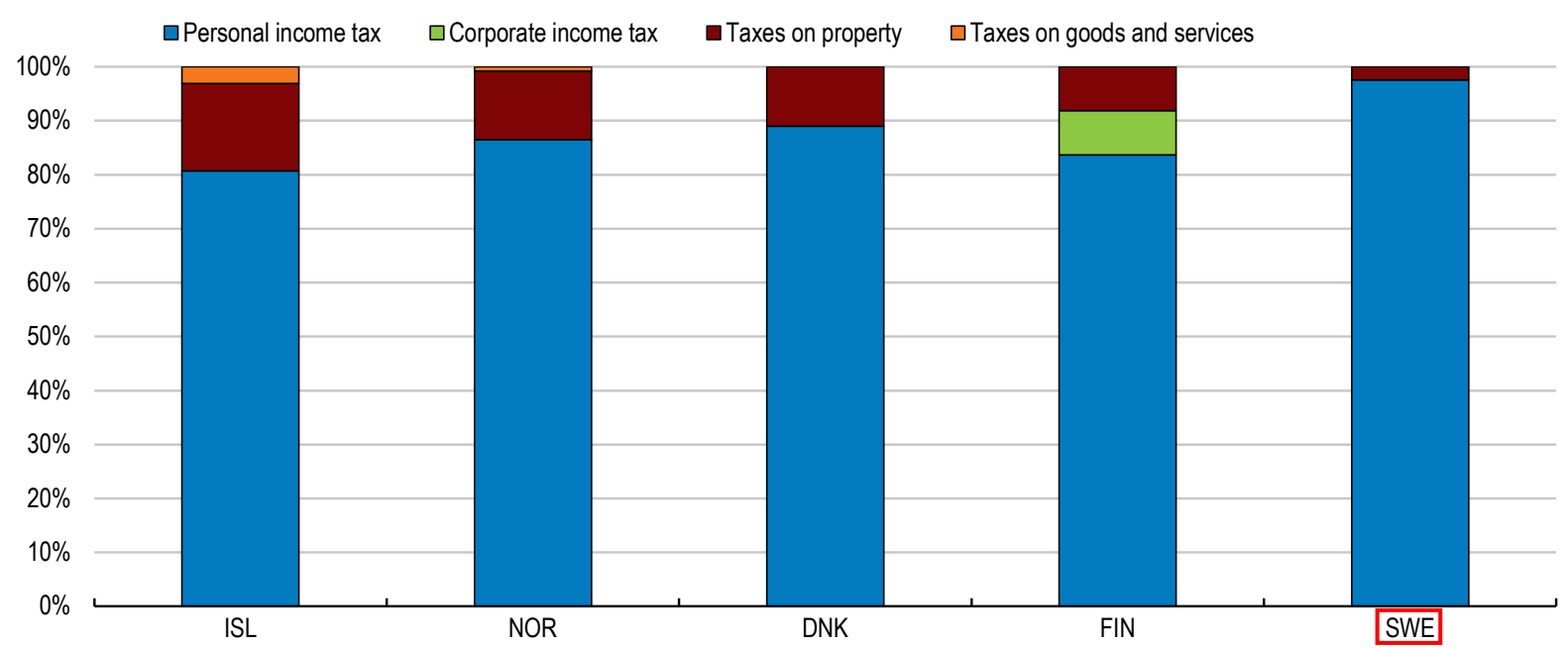




\section{The equalisation system compensates most differences in tax capacity and costs}

The fiscal equalisation system aims at enabling sub-national governments (regions and municipalities) across the country to provide equal access to public services, despite differences in demography, taxing power and costs. Similar systems of revenue and cost equalisation are in place for regions and municipalities (Box 2). Equalisation transfers amount to more than $4 \%$ of government expenditure, which is slightly above the average of OECD countries with available data. However, the size of equalisation transfers varies widely across countries, partly reflecting differing administrative structures and responsibility allocation (Figure 8 ). Revenue equalisation accounts for nearly $90 \%$ of equalisation transfers in Sweden (Figure 9). Equalisation systems with a dominant revenue component tend to reduce income differences much more than systems with a strong cost-equalising component. In Sweden, fiscal equalisation is estimated to reduce revenue inequality between municipalities (measured by the intermunicipal Gini coefficient of per capita revenue) by a third, which is close to the average of OECD countries for which data are available (Dougherty and Forman, 2021). Germany provides an example of a wellfunctioning system based on vertical revenue redistribution with a horizontal equalising effect (Box 3 ).

Cost equalisation systems are much more complex than revenue equalisation systems and their outcomes are much more difficult to assess, as they cannot be summarised in a simple revenue disparity indicator. Sweden has one of the most comprehensive cost equalisation systems in the OECD, along with Australia (Figure 10). The use of sophisticated sectoral expenditure models allows a wide-ranging assessment of structural differences in the per capita costs faced by municipalities and regions, albeit at the price of perceived complexity and lack of transparency. The latest review of the equalisation system could only propose relatively minor simplifications, but dismissed claims that the system was incomprehensible (Swedish government, 2018). Nevertheless, as many stakeholders seem to find the system too complicated, it would be desirable either to simplify it, as far as this can be done without neglecting important factors, or to present it in a more transparent way.

\section{Figure 8. Equalising transfers are slightly above peer countries’ average}

Percentage of total government expenditure

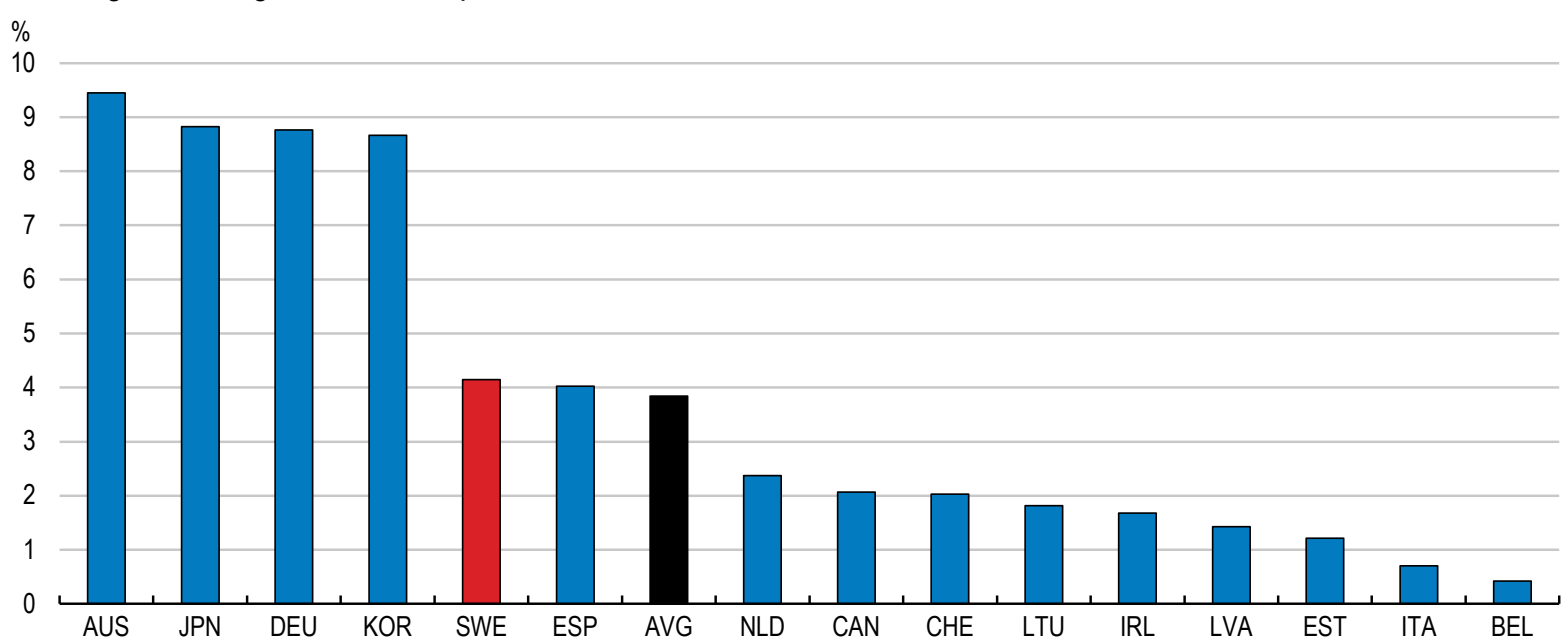

Note: Data is from 2017 or latest year available. Only systems of explicit fiscal equalisation are included, other systems of inter-governmental transfers which may include equalising criteria are not included in this figure. The figure for Belgium is based on revenue equalising transfers to regions only. AVG is the unweighted average of the countries included in the figure.

Source: Dougherty and Forman (2021), "Evaluating fiscal equalisation: finding the right balance", OECD Working Papers on Fiscal Federalism, No. 36, OECD Publishing, Paris. 
Figure 9. Revenue equalisation is predominant in Sweden

Expenditure on cost and revenue equalisation as a share of total expenditure on equalisation, 2018

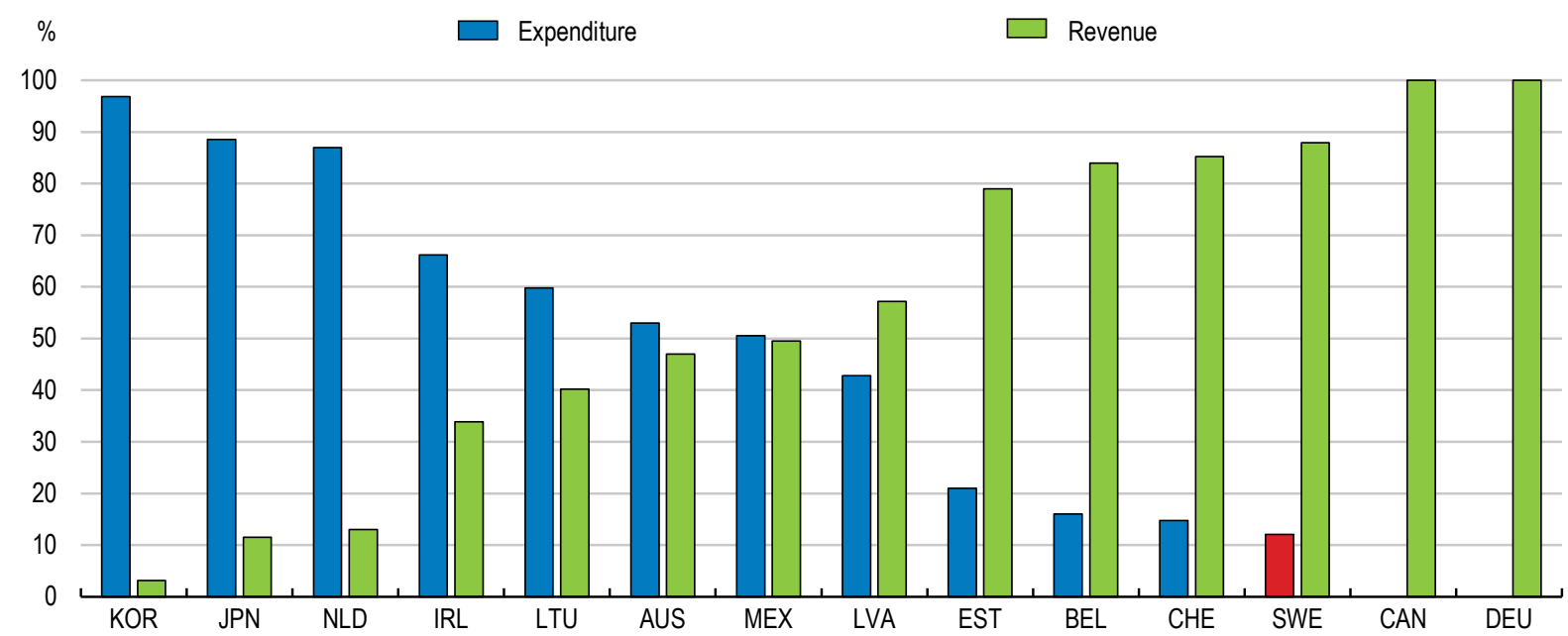

Note: This figure depicts the relative shares of cost and revenue equalisation as a percentage of total expenditure on equalisation.

Source: Dougherty and Forman (2021), "Evaluating fiscal equalisation: finding the right balance", OECD Working Papers on Fiscal Federalism, No. 36, OECD Publishing, Paris.

Figure 10. The Swedish cost equalisation system is relatively complex

Number of variables and number of factors entering into cost equalisation formulas
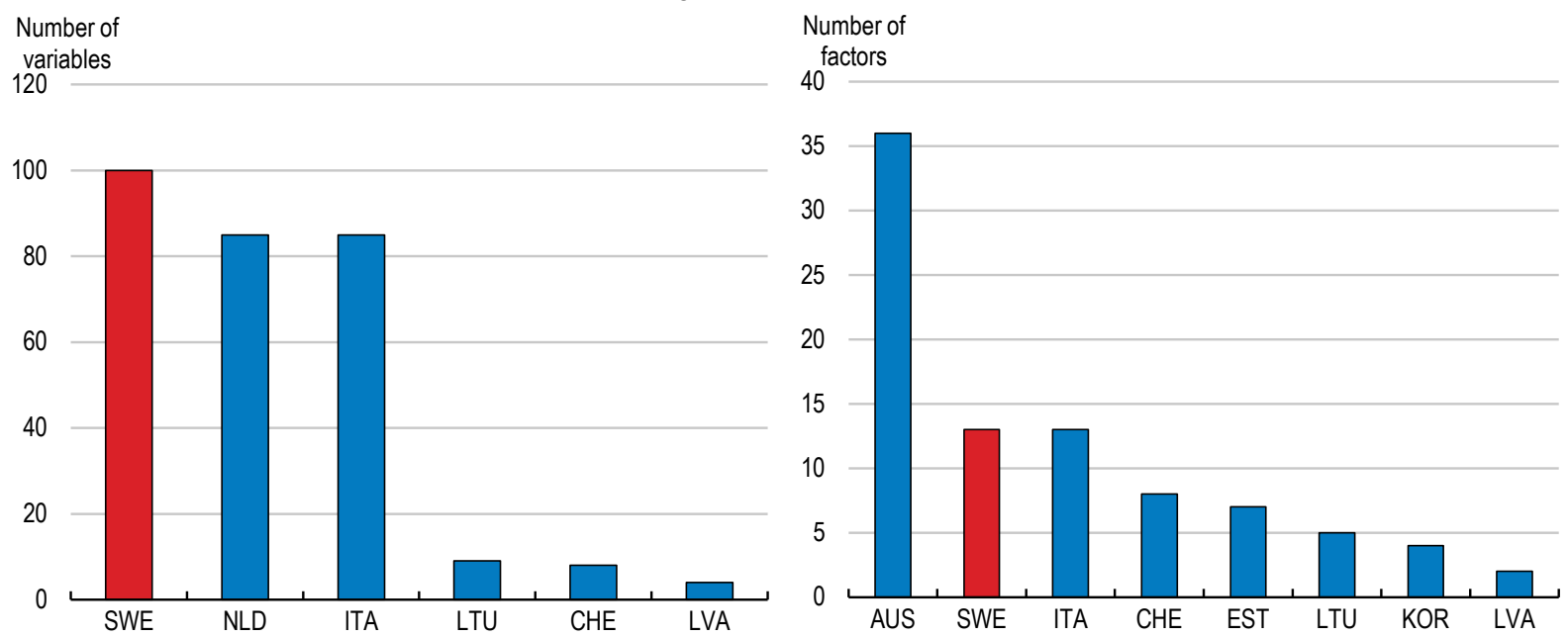

Note: $A$ factor is a driver of cost disparity, such as a public service or a geographic feature, rather than a variable which enters directly into a formula. Factor are quantified by one or more variables.

Source: Dougherty and Forman (2021), "Evaluating fiscal equalisation: finding the right balance", OECD Working Papers on Fiscal Federalism, No. 36, OECD Publishing, Paris. 
vintage of the cost equalisation system is in place. The present COVID-19 crisis could also have important implications for the transfers, and a rapid evaluation of the system may be useful. Parliament has called for a new general review of the whole tax equalisation system and asked the government to start an inquiry in December 2020.

\section{Box 2. Overview of the equalisation system and new features introduced in 2020}

\section{Organisation and principles}

Fiscal equalisation in Sweden relies on two separate equalisation systems, one for municipalities and one for regions, both with a revenue and a cost component. ${ }^{1}$

The income equalisation system is based on taxing power, measured by the tax base per inhabitant. The tax rate used in the calculation of the tax base is a representative tax rate fixed by Government to avoid that different tax rates across jurisdictions affect redistribution. The sub-national governments with taxing power below $115 \%$ of the country average receive a grant from the state, while those with higher taxing power pay a contribution. Only 14 out of 290 municipalities and one region out of 21 pay a contribution and the central government finances $95 \%$ of the grants.

The cost equalisation system compensates for structural cost differences depending on demographics, resident needs and production conditions, like wage levels and geography. The cost equalisation models for municipalities and regions consist of respectively nine and three sub-models, related either to areas of activity (e.g. elementary schools; elderly care; public transport) or to operating conditions and demographics. Efficiency, the range of services provided, or the level of user fees must not affect redistribution to avoid perverse incentives. Contrary to the income equalisation system, the cost equalisation system is entirely horizontal, with no contribution from central government. About a hundred municipalities and ten regions are net contributors.

\section{The 2020 enhancements}

The latest vintage of the cost equalisation system came into force at the start of 2020. It retains most previous sub-models, but introduces significant changes and updates to better account for differences in structural needs and costs. In particular, the new system better accounts for higher costs related to sparse and declining populations and socio-economic differences, including those related to the reception of refugees. It adds a new sub-model for adult education, including Swedish language for immigrants. The new formula for individual and family care standard costs removes variables dependant on the actual number of beneficiaries, which generated perverse incentives. The level of education enters the health formula to reflect the impact of socioeconomic conditions on health (Swedish government, 2018, 2019b).

The system also becomes more consistent, with the integration of demographics and operating conditions (e.g. building structure, wages) into the areas of activity sub-models, rather than in separate sub-models. Exceptions are a general expenditure component for municipalities accounting for population decline, payment delays, heating, construction and administration costs, and a population growth component for regions.

A special introduction grant ensures that changes in the system do not increase annual costs for individual municipalities and county councils by more than SEK 250 (EUR 25) per inhabitant.

In December 2020, Parliament asked for a new inquiry to review the entire municipal economic equalisation system, with a focus on development, growth and equal service throughout the country.

1. Both systems also include two components aimed at compensating sub-national governments for past reforms (structural allowance and introduction allowance) and an adjustment item.

Source: Swedish Association of Local Authorities and Regions; Swedish Government (2018, 2019b). 


\section{Box 3. The German fiscal equalisation system}

Germany differs substantially from Sweden, as it is a federal country, and equalising transfers are larger (Figure 8). Nevertheless, some mechanisms it uses for fiscal equalisation may be a source of inspiration, even though institutional and cultural differences prevent direct transposition. The German system is based on revenue equalisation (Figure 9), although differences in needs and costs are taken into account. In short, the transfer system provides vertical redistribution with a horizontal equalising effect.

\section{Responsibility assignment across government levels}

The main central government budget expenditure items relate to defence, social security and labour market policy. The 16 states (länder) spend most on education, internal security, justice and administration. About 11000 municipalities provide social benefits (including assistance for youth and childcare), culture, sport and recreation, and local services, such as water and waste management. Financing largely relies on shared taxes, notably corporate and personal income taxes and VAT, even though municipalities also have their own fiscal resources, mostly from property and local business taxes. To account for differences in fiscal capacity and needs between and within states, two equalisation systems are in place. The Constitution prohibits direct financing of municipalities by the federal government.

\section{Equalisation between states}

A new system entered into force in 2020 , to adjust to the expiration of special transfers to Eastern German states in 2019 and the introduction of a "debt brake" to limit debt-financed expenditure by 2020. The states unanimously accepted the reform, which strengthens their finances, in exchange for stricter control. The system also strengthened vertical redistribution, notably through greater VAT distribution to the states. As a result, from 2020 , no state has to budget equalisation expenditures, which reduces potential tensions from perceived overburdening.

The Constitution guarantees equivalent living conditions across the country. Semi-determined norms acknowledge regional differences and preserve local autonomy to adapt local service provision to local conditions and preferences. The main horizontal equalisation factor is population, but adjustments account for specific needs. The reference population is increased in the City states (Berlin, Hamburg and Bremen), mainly to account for the provision of services to surrounding areas, and in some sparsely populated states to account for diseconomies of scale. States can also receive non-earmarked federal grants to compensate for specific disadvantages, such as high fixed administration costs due to small size or public infrastructure needs.

\section{Equalisation between municipalities}

Redistribution to municipalities within each state allows the provision of equivalent services despite varying fiscal capacity and needs. Formula-based grants, non-earmarked to preserve municipal selfgovernance, transfer funds from the state to municipalities with lower fiscal capacity than spending requirement. In most states, no contribution is required from municipalities with excess fiscal capacity, which keeps the system entirely vertical. Equalisation formulas are generally based on adjusted population numbers, as for equalisation between states. However, some states use more sophisticated formulas, including a broad range of demographic and socio-economic factors.

Source: Thöne, M. and J. Bullerjahn (2018), "Reform and future of federal fiscal relations in Germany", Deutsche Gesellschaft für Internationale Zusammenarbeit, Hamburg; Thöne, M. and J. Bullerjahn (2020), "Municipal finances and municipal financial equalisation in Germany”, Deutsche Gesellschaft für Internationale Zusammenarbeit, Hamburg; Deutsche Bundesbank, Monthly Report, September 2014. 


\section{Regions and municipalities face diverse challenges}

About $40 \%$ of the Swedish population lives in the three metropolitan areas with more than half a million inhabitants each (Stockholm, Gothenburg and Malmö). Concentration in cities of this size is lower than the OECD average, but higher than elsewhere in Europe. Cities between 50000 and half a million inhabitants house a much smaller share of the Swedish population than the European average and $43 \%$ of the population lives in areas with less than 50000 inhabitants (Figure 11). The three biggest cities face challenges related to rapid urban growth, such as stress on infrastructures and housing shortages, the need to accommodate growth while reducing carbon emissions, and social polarisation, while small cities and rural areas have to deal with small scale and in some cases remoteness, population shrinkage and labour shortages.

The share of both young and old people has risen markedly over the past decades and the dependency ratio is set to increase further over the next decades (Figure 12). However, the national ratio masks regional divergence, with a relatively stable dependency ratio in Stockholm until the end of this decade, contrasting with continued increases in other regions. By the end of the 2020s, the gap between the highest and lowest dependency ratios is expected to be above 20 percentage points, more than twice its 2010 level. Increases in Västra Götaland and Skåne are close to the national average, but the median is much higher, reflecting an increasing burden outside the main metropolitan areas. Demography-related fiscal costs are expected to increase by $9 \%$ between 2018 and 2030. Except for the largest metropolitan areas, cost increases are largely unrelated to size (SKR, 2020a). The central government is increasing grants to regions and municipalities, to help them cope with this burden without raising taxes or lowering the provision or quality of public services (see below). Nevertheless, even with more financial resources, providing adequate public services in small or remote jurisdictions is becoming increasingly challenging, due to a lack of scope for economies of scale and shortages of qualified workers.

\section{Figure 11. A large share of the population is concentrated in the three main cities}

Panel A. Sweden, percentage of population in cities

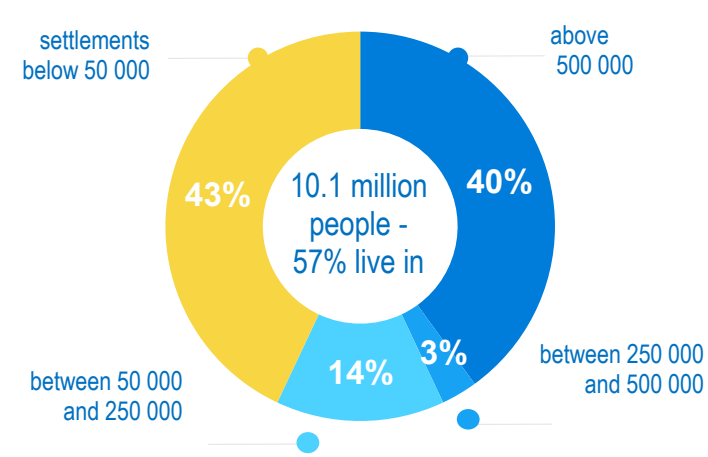

Source: OECD Regions and Cities at a Glance 2020.
Panel B. Population by city size, a global view

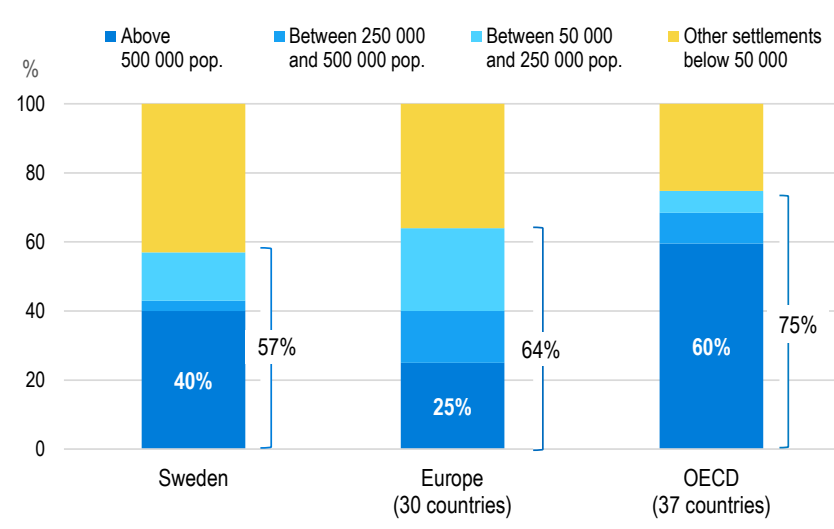

Access to public services and outcomes vary significantly across places. School results are uneven across regions, even after taking into account other determinants, such as the socio-economic background of students (André et al., 2020). Disparities in the share of adults with tertiary education are also important, partly reflecting the concentration of universities in regions like Stockholm and Western Sweden. In 2019, $53 \%$ of the population aged 25 to 64 had tertiary education in the Stockholm region, while this share was only $34 \%$ in North Middle Sweden (André and Pak, 2021). Access to lifelong learning, which offers better job opportunities and where Sweden has the highest ranking among OECD countries, is lower in predominantly rural regions. In 2019 , about $30 \%$ of the population aged 25 to 64 participated in formal and 
non-formal education and training in North-Middle Sweden, below the 34\% national average and regions like South Sweden and Stockholm (36\%). Access to health care varies across regions (Blix and Levay, 2018; Blix and Morin, 2020), partly reflecting the uneven distribution of medical resources around the country. In 2017, about five physicians were available for 1000 persons in the Stockholm region, which is almost $40 \%$ higher than in North-Middle Sweden. The number of hospital beds has decreased in all regions between 2000 and 2018 and is one of the lowest among OECD countries (about two beds for 1000 persons, while Austria had about seven).

Before the COVID-19 crisis, Sweden displayed high overall employment, with unemployment mostly affecting foreign-born and low-skilled workers. Shortages of skilled labour surfaced in both the public and private sectors in the late 2010s, especially in education, data and IT, technical and scientific professions, construction, health care and installation, operation and maintenance (Arbetsförmedlingen, 2019a). The COVID-19 crisis affects sectors differently, with in particular increased demand for health professionals and data and IT specialists and weak demand for workers in jobs requiring face-to-face interaction. The effect of the crisis on public services over the coming years is unclear as yet. On the one hand, demand for workers will increase in some activities where the crisis has highlighted shortcomings, notably elderly care, and difficult working conditions during the pandemic seem to have prompted more staff than usual to leave health professions. On the other hand, weaker prospects in the overall labour market, especially in private service activities, may make public sector jobs more attractive. Government initiatives have increased teacher remuneration in recent years to make the profession more attractive (OECD Economic Survey of Sweden, 2019) and similar efforts may be needed for other categories of professions with rising shortages. However, in some professions, improving working conditions may be even more important than pay levels to attract and retain qualified workers.

Figure 12. Dependency ratios are increasing and diverging across regions

Ratio of population aged below 15 or over 64 to population aged 15-64 (\%), TL3 regions

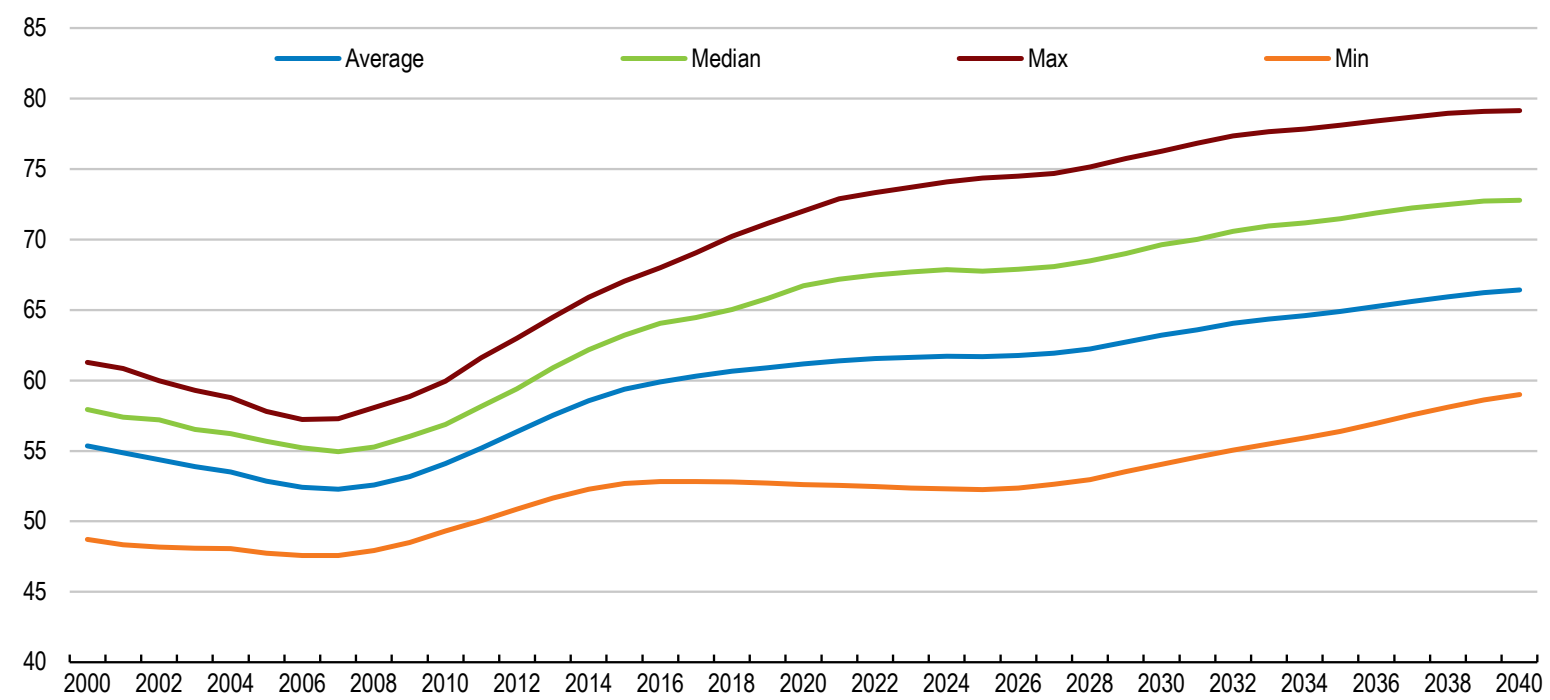

Note: The minimum corresponds to the Stockholm region throughout the period. The maximum corresponds to different regions depending on the year.

Source: Statistics Sweden and authors' calculations.

Labour shortages vary widely between regions. Earlier OECD analysis pointed to a high skills equilibrium (high supply and demand for skilled workers) in the three leading regions, a low skills equilibrium (high supply and demand for low-skilled workers) mainly in some southern regions, and a skills deficit mainly in northern regions (OECD, 2015b). A shrinking workforce driven by youth out-migration and low retention of migrants is a particular bottleneck in Upper Norrland, which enjoys competitive advantages to become a 
global leader in environmentally sustainable mining. Labour shortages also vary markedly within regions, between cities and sparsely populated areas. Small and medium-sized municipalities find it particularly difficult to increase employment as they would like for lack of skilled workers. Shortages in rural areas are most acute in business and welfare services and construction, while matching is also less efficient than in more densely populated areas (Tillväxtverket, 2020). Population ageing will further limit labour supply going forward, pointing to the need to increase employment rates and lengthen working lives.

Wage flexibility across regions is crucial to maintain high employment in regions with uneven productivity developments. Wage bargaining in Sweden takes place within an organised decentralised framework, with predominant sectoral level negotiations and high coordination (OECD, 2019a). The manufacturing sector sets a benchmark, which other sectors tend to follow closely. However, the system leaves room for substantial firm-level flexibility. In the 2020 bargaining round, approximately $45 \%$ of employees had their wages negotiated at the local level. Wages react to regional unemployment in most sectors. A doubling of the unemployment rate in a region is estimated to lower private sector wages by $2.5 \%$ in the short run and $7.5 \%$ in the long run. Furthermore, the wages of workers most at risk of job loss or those exiting unemployment react most strongly to the regional unemployment level (Carlsson et al., 2019).

As noted above, the employment rate has increased significantly in some sparsely populated regions, but achievements remain uneven across the country. The foreign-born provide the largest potential to increase labour supply, especially for women, whose employment rate (age 16-64) lagged that of natives by 21 percentage points in 2020. Bringing the employment rate of the foreign-born to the level of natives would add 134000 women and 87000 men to employment, or about $45 \%$ of the 485000 needed to stabilise the employed-to-population ratio by 2030 (Arbetsförmedlingen, 2019b). However, the foreign-born generally have lower education than natives. Job matching is relatively weak, especially for people from low-income countries, and even more so in more remote areas (Tillväxtverket, 2020). Policy measures to address this challenge include developing adult education further, in cooperation with the social partners (OECD Economic Survey of Sweden, 2019), improving transport to enlarge labour markets (Tillväxtverket, 2018), and increasing opportunities for distance learning and teleworking (see below).

Efforts to raise the employment rate of foreign-born women are essential. Many drift away from the labour market after the end of the Introduction programme, which supports immigrants during their first two years in Sweden (OECD, 2016a; OECD Economic Survey of Sweden, 2017). The government has, in addition to general measures to speed up the integration of newly arrived immigrants, taken initiatives focusing on foreign-born women, like funding to increase the possibilities for persons on parental leave to take part in Swedish language courses and training, as well as targeted outreach and study motivation actions (OECD Economic Survey of Sweden, 2019). A pilot programme for the integration of foreign-born women in the labour market is showing promising results and should be expanded (see Box 1.3 in Chapter 1 of the OECD Economic Survey of Sweden, 2021).

The combination of declining population and low productivity growth in remote areas threatens the cohesion of society (Enflo, 2016). In response, the government introduced in 2020 a tax rebate aimed at people living in sparsely populated areas, particularly in Northern and Western Sweden. Maintaining access to public services in these areas is both challenging and essential to break down negative dynamics leading to further population outflows. While the extension of digitalisation offers opportunities to provide some services remotely (de Mello and Ter-Minassian, 2020), maintaining a certain degree of physical presence remains essential in some areas, including police, social and employment services (Swedish government, 2020a).

Larger cities face the challenges of accommodating growing populations in a sustainable way. This concerns the three main metropolitan areas, but also intermediate size cities, as the number of municipalities with a population over 100000 inhabitants is expected to increase from 18 to 27 by 2040 (Swedish government, 2020b). The main Swedish cities are at the forefront of smart and green growth. Stockholm has developed its "Vision 2040" to respond in an innovative way to sustainability challenges 
(Box 4). Gothenburg has taken advantage of the region's strong vehicle cluster to move quickly toward clean transport, with more than 200 electric buses at end-2020, and an objective of fossil-free public transports by 2030 . The city is also developing new neighbourhoods hosting both businesses and housing. Malmö is transforming its old dockyards into a carbon-neutral district, relying on wind, solar and biogas energy, which is set to house more than 10000 people when completed.

\section{Box 4. Stockholm's strategy for a smart and sustainable city: Vision 2040}

Stockholm's city council outlined its "Vision 2040" in 2017 to address the challenges from climate change, rapid urbanisation and increasing global competition, with the stated goal of becoming the smartest city in the world by 2040 . Having a history of environmental and climate initiatives going back to the mid-1970s, Stockholm now has the ambition to take advantage of its leading position in information technologies and the presence of numerous innovative companies to become fossil free and climate positive by 2040 (Stockholms stad, 2020). Its innovative waste recycling system allows moving towards a circular economy and producing energy, notably for district heating. In June 2020, Stockholm's city council revised its "Vision 2040", in collaboration with government officials, companies and citizens, setting three main goals: a versatile big city for everyone; a smart and innovative city; and a sustainably growing and dynamic city.

Stockholm was awarded the World Smart City Award 2019 by the GrowSmater project sponsored by the European Union for its innovations to reduce energy use, enhance connectivity and improve residents' well-being (European Commission, 2019a). Its region is the most innovative in Sweden and one of the most innovative in Europe, ranking second in the European Commission regional innovation scoreboard 2019 (Figure 13).

\section{Figure 13. Stockholm is one of the most innovative regions in Europe}

EU average $=100$
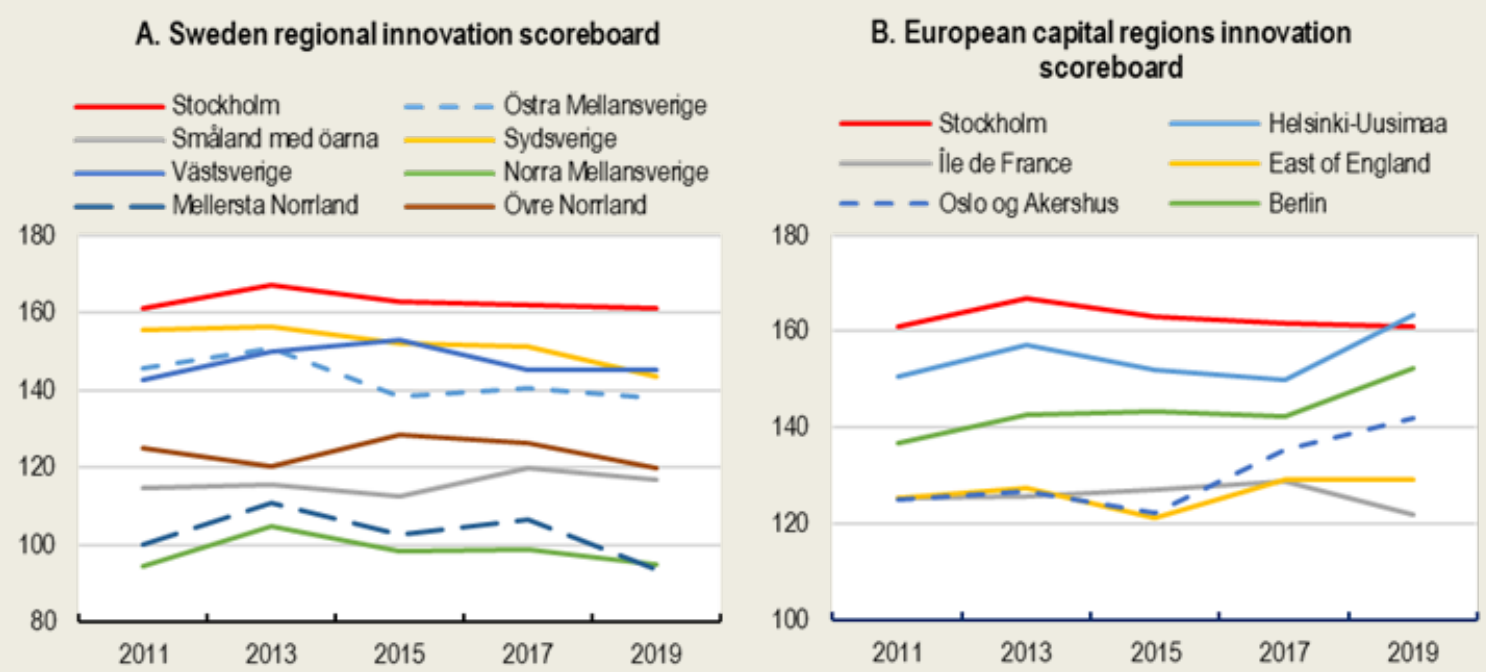

Note: Scoreboard measures may overstate regional differences if they do not fully capture innovations within the smallest companies, which are overrepresented in rural regions.

Source: EU Regional Innovation Scoreboard (2019).

Source: Stockholms stad (2020), Möligheterna Stockholm - Vision 2040 (Stockholm of opportunities); European Commission (2019a), Stockholm wins World Smart City Awards for European Project, press release, 27 November 2019.

Moves towards a circular economy are not confined to the major cities. For example, Växjö stated the goal of being fossil-free by 2030 as early as 1991 and has made great progress since then, notably by using 
biomass for district heating, recycling waste, and developing clean public transport. In addition, these innovations have benefitted the local economy and the city is at the centre of a region (Kronoberg) with one of the fastest productivity growth rates since 2000. Umeå is developing a circular economy strategy with the goal of being fossil-free by 2040 , while enhancing innovation and creating the enabling environment for new business models (OECD, 2020a).

Nevertheless challenges remain. Housing shortages, particularly of affordable rental housing are widespread and acute in big cities, notably Stockholm. Social polarisation is also increasing and safety is an issue in some areas. In response, the government has increased subsidies for municipalities facing socioeconomic challenges and those with a high level of refugee reception, as well as funding for the police. More generally, the government has strengthened its support to regional and local authorities.

\section{The central government is increasing its support to municipalities and regions}

Real municipal revenue and expenditure increased on average by about $1 \%$ per year over the past decade (Figure 14). Spending increases were mainly driven by education costs, reflecting demographic developments, including strong immigration, and efforts to improve quality (OECD Economic Survey of Sweden, 2019). Revenue increases were almost equally split between additional tax revenue and additional grants from central government. Several sub-periods need to be distinguished. From 2009 to 2014 , spending increases were moderate and mostly covered by general grant and tax revenue increases. The 2015 refugee crisis pushed up spending on items related to the integration of immigrants. Earmarked grants increased sharply and strong economic growth over 2014-17 generated healthy tax revenue, with municipal income outpacing spending. This was reversed from 2018, as growth subsided and earmarked grants declined more than other spending. The regions' real expenditure increased by $1.8 \%$ per year on average over 2009-19. The faster rise in spending than for municipalities mainly reflects the rising cost of health care, but infrastructure spending, which accounts for nearly $10 \%$ of regional expenditure grew even faster, by close to $8 \%$ annually in real terms, reflecting adjustments related to population increases and the need for renewal of old structures.

In 2019, around a quarter of municipalities and more than a third of regions were in deficit. The government increased its general grants to sub-national governments by around $0.7 \%$ of GDP in 2020, partly to allow them to deal with rising welfare costs induced by demographic change. The largest part of the increase in general grants, SEK 21 billion, was intended to compensate for the economic effects of the COVID-19 pandemic, but SEK 12.5 billion constitute a permanent increase in general grants. Pandemic-related grants generally exceeded additional costs and revenue shortfalls, leading to the expectation of the first subnational government surplus in ten years (SKR, 2020b). Nevertheless, the challenges outlined above remain, calling for the central government to continue monitoring closely the adequacy of financing to maintain the quality of welfare service provision throughout the country and for municipalities and regions to continue their efforts to raise efficiency.

The central government may need to increase grants to municipalities and regions further in the coming years to ensure adequate service provision. One issue is the revaluation of grants, which is not automatic. While linking the evolution of grants to an index, for example of wage increases, as labour costs amount to a large share of spending, would provide more visibility to sub-national governments, discretion offers flexibility to address specific situations. Nevertheless, the government should make sure that grant revaluations reflect evolutions in costs over which local authorities have little control. Another issue is maintaining service standards in the face of increasing demand for public services, notably due to demographic trends.

This raises the question of the most adequate type of grants. General grants provide flexibility to adapt to local needs and are usually preferable, even though in some cases, earmarked grants may be necessary to ensure that money allocation is consistent with key government policy objectives. Narrowly defined 
earmarked grants in terms of use and time span are difficult to use. They increase the administrative burden and offer less visibility to sub-national authorities than general grants (OECD/KIPF, 2016). Greater reliance on earmarked grants can draw subnational government attention away from local needs and preferences, distorting decision making and impacting allocative efficiency (OECD, 2017a). Moreover, the combination of municipal core funding and responsibility with targeted grants aimed at achieving specific policy goals may be sub-optimal and a poor substitute for better central government steering and coordination across levels of government (OECD Economic Survey of Sweden, 2019; Pareliussen et al., 2019). They also implicitly assume that different jurisdictions face similar issues, which is not always the case (Blix and Morin, 2020). As Figure 14 shows, earmarked grants increased rapidly after 2014, partly due to the refugee crisis, even though they were subsequently scaled back somewhat. Ideally, earmarked grants should be restricted to areas where they have a clear advantage.

Along with additional financial resources, maintaining the availability and quality of public services as labour shortages worsen will require reorganisation and innovation. Responsibility assignment and financing is worth reconsidering in some areas:

- Given the low employment rate of immigrants after the two-year integration period and that municipalities are financially responsible for persons claiming social assistance, the financing for integration may need to be re-examined (OECD, 2016a).

- National-level financing of personal assistance for people with disabilities should replace cofinancing between municipalities and central government to better align financing with decision power. This would also allow better risk-pooling. Currently, a few disability cases can heavily burden the finances of a small municipality.

\section{Figure 14. Contributions to municipal spending and revenue}

Annualised contributions to real growth, \% points
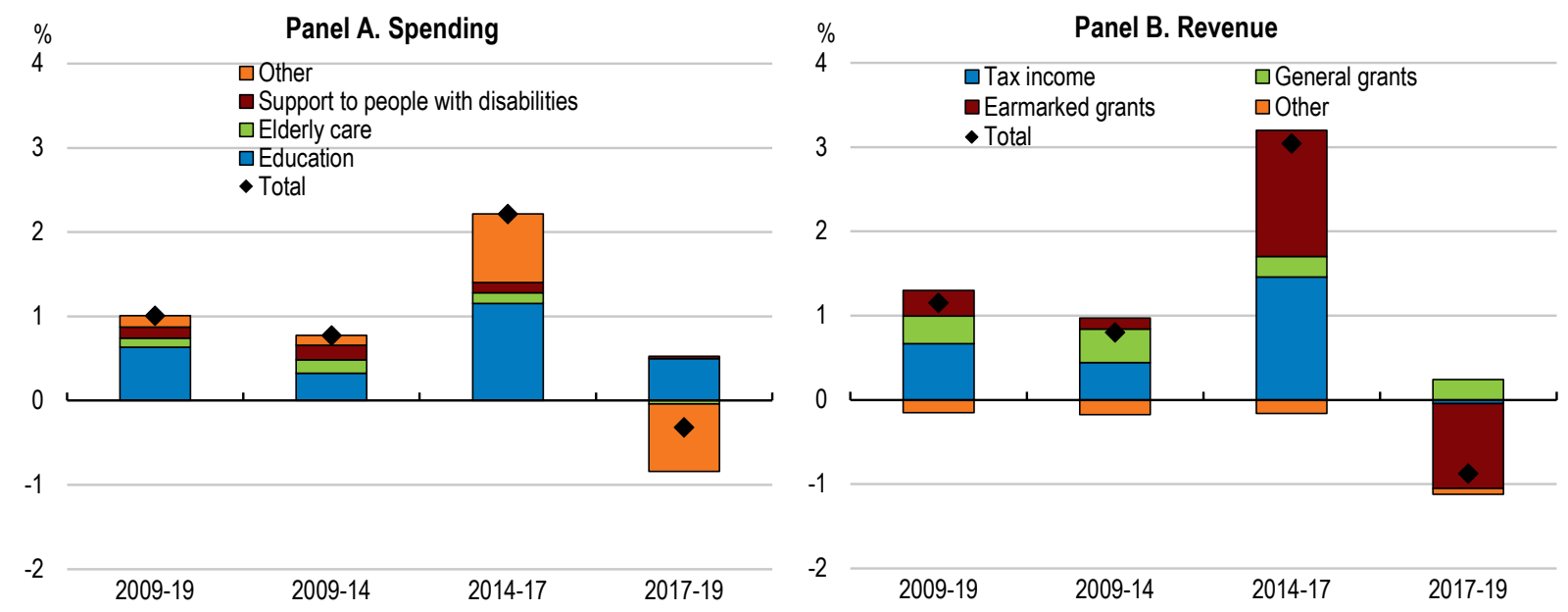

Note: Real values are obtained using the government consumption deflator.

Source: Swedish Association of Local Authorities and Regions.

Stronger cooperation between municipalities or mergers may bring efficiency gains. The advantages of much debated municipal mergers are not always clear, as they can bring economies of scale and scope, but weaken local democracy and responsiveness to local needs. While voluntary mergers may be beneficial in some cases, strategic inter-municipal cooperation in relevant fields may be a more flexible way to enhance efficiency in others. Furthermore, mergers may bring little advantage for remote areas, 
where municipalities cover a wide territory (OECD, 2017a; Swedish government, 2020b; SKR, 2020a). While inter-municipal cooperation has intensified in recent years, there is scope to reinforce strategic approaches to improve efficiency. Stronger strategic cooperation between municipalities and regions to promote coherent development, along with intensified consultation and dialogue and rigorous project evaluation, could help.

More flexible institutional arrangements can also facilitate the joint provision of public services by several municipalities. The Local Government Act was amended, as of 1 July 2018, to make it possible for municipalities and regions through contractual cooperation to delegate decision-making rights in all activities to an employee in another municipality or region. The amendment aims at facilitating the provision of high quality and equal services throughout the country and is particularly important for small municipalities that may experience difficulties in recruiting specialist competences. Several other OECD countries have reinforced their institutional framework in recent years to promote strategic inter-municipal cooperation, including Austria, Chile, New Zealand and the Slovak republic (OECD, 2017b). For example, 2014 amendments to the New Zealand Local Government Act encourage collaboration and shared service delivery by local authorities (New Zealand Department of Internal Affairs, 2021).

Strategic multi-level governance also needs to improve. Strategies and roadmaps for different sectors, industries and technology areas at European, national, regional and local level remain insufficiently connected to each other. The strategic priority areas defined in the 2021-2030 National strategy for sustainable regional development (see above) could constitute a basis for a more holistic approach (Swedish government, 2021). Multi-level consultation and dialogue on strategic objectives would strengthen coordination between regions, municipalities and other stakeholders, like education institutions or business and civil society organisations.

Several studies comparing performance either across entities within Sweden or with foreign counterparts point to scope for some efficiency improvements in the provision of public services, but most efficiency differences between municipalities remain unexplained. This suggests they are not related to simple and measurable factors, but rather to management quality, notably in terms of budget administration, human resources and responsibility assignment (Blix and Morin, 2020 and references therein). A more general potential source of efficiency gains is through better use of digital tools.

\section{Digitalisation offers opportunities to enhance public service delivery}

Advances in technology offer vast potential to enhance productivity, even in services, if combined with the right policies (Blix, 2015; Sorbe, Gal and Millot, 2018). Achieving efficiency gains becomes all the more important as ageing strains financial and human resources. Furthermore, e-government, distance learning and telemedicine improve access in remote areas, even though they cannot fully substitute physical services. Telemedicine was already expanding quickly before the COVID-19 pandemic (Blix and Jeansson, 2018; Oliveira Hashiguchi, 2020) and has gained further momentum during the pandemic. Education also went partly online, helped by the widespread availability of digital tools, although not without pedagogical challenges (Bergdahl and Nouri, 2020). Online services expanded in many other public services, for example the Public Employment Service. Developments triggered or accelerated by the pandemic provide a strong basis for further expansion of permanent digital public services (de Mello and Ter-Minassian, 2020).

Sweden is among the leading countries in the diffusion and use of digital technologies (OECD, 2018) and in e-government (Figure 15). The use of cash is declining rapidly in favour of digital payments. The share of Internet users who used the web for online banking or purchasing, or to submit completed forms or interact with public authorities, is one of the highest among OECD countries (André and Pak, 2021). More than $96 \%$ of households had access to the Internet in 2019 , but high-speed broadband remains limited in 
rural areas (Figure 16). However, the government has allocated additional funding for the expansion of broadband over the coming years.

Figure 15. Sweden is among the world's leading countries in e-government

Top performers in e-government

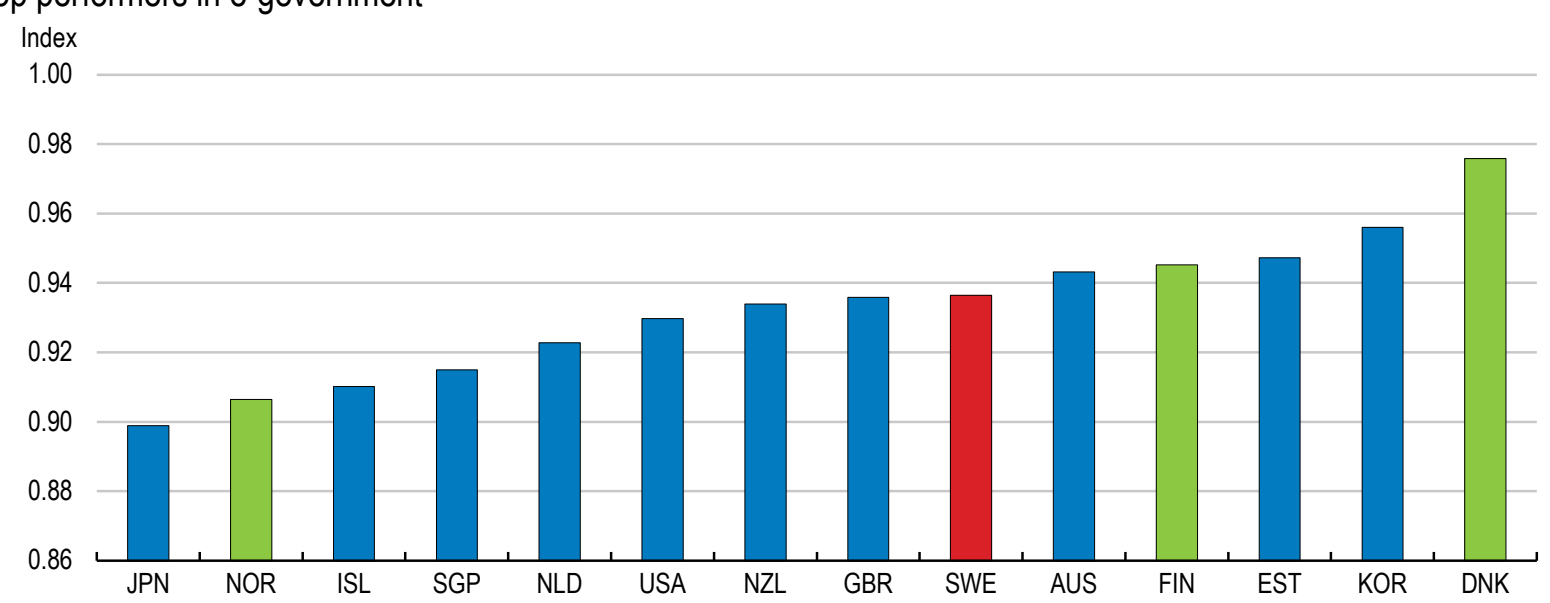

Source: 2020 United Nations E-Government Survey.

Figure 16. Access to high-speed broadband remains limited in rural areas

Percentage of households with access to Internet $>30 \mathrm{Mbit} / \mathrm{s}$ in 2019 or latest available year, at the rural and national levels

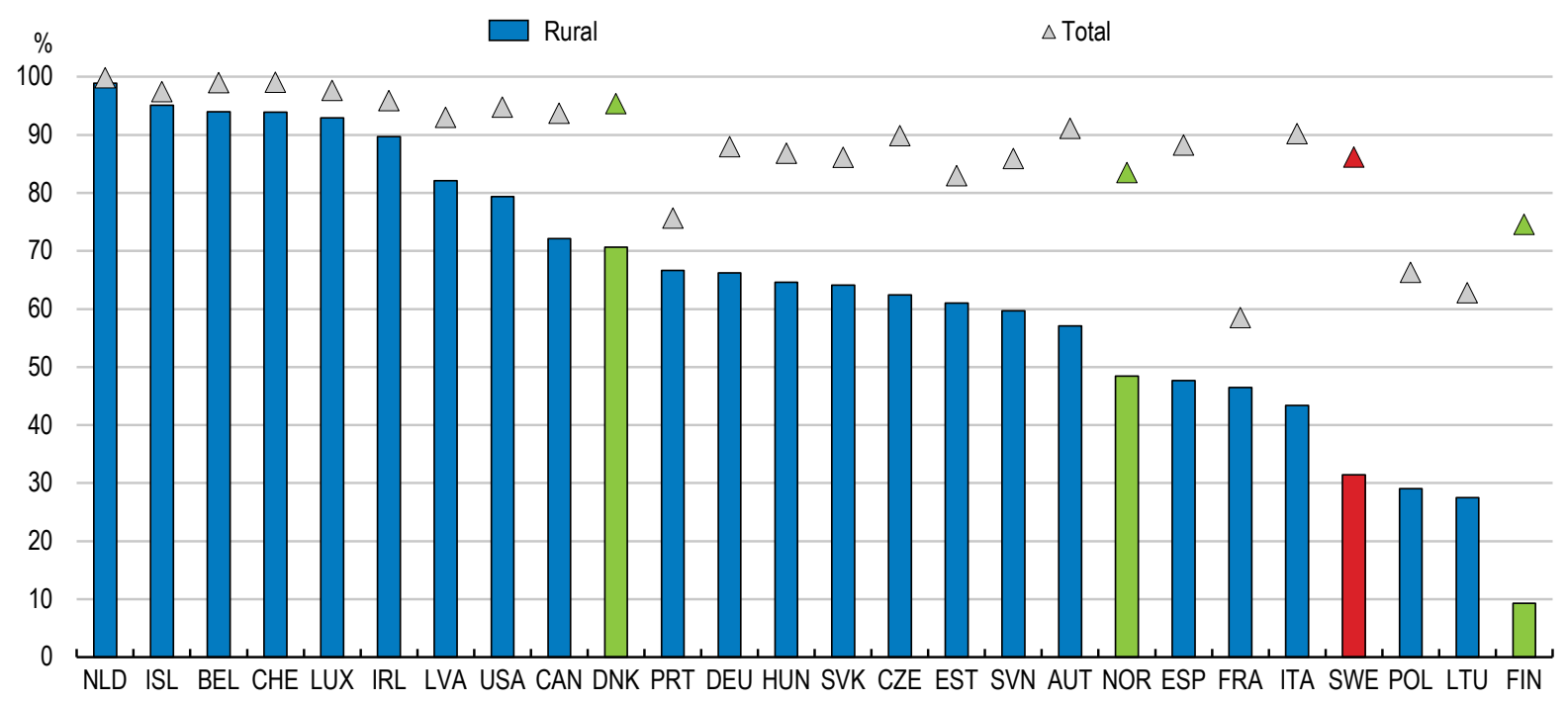

Note: 2019, or last available year: EU countries (2018). Internet access is expressed as the percentage of households (population, for the United States) with access to fixed broadband technologies with download speed greater than 30Mbit/s (NGA technologies, for the EU). For EU countries, rural areas are those with a population density lower than 100 inhabitants per square kilometre. For Canada, rural areas are those with a population density less than 400 per square kilometre. For the United States, rural areas are those with a population density less than 1000 per square mile or 386 people per square kilometre.

Source: Calculations based on OECD Regional Statistics database.

Digital transformation is demanding for municipalities, particularly the smaller ones with limited resources and technical expertise (Swedish Government, 2020b). The government has a central role to play in supporting them and developing a coherent digital infrastructure, allowing easy access to information and 
services and smooth data exchange, while preserving security and privacy. Sweden has an ambitious digitalisation strategy, focussing on skills, security, innovation, management and infrastructure. Digitalisation is a priority across ministries and government agencies. The strategy aims at promoting smart cities, but also sustainable rural areas through digitalisation. Recent initiatives support the strategy, including the creation in 2017 of a Digital Council, aimed at providing leadership and coordination in digitalisation policy and of a new Agency for Digital Government in September 2018 to coordinate and support public sector digitalisation. The appointment of regional digitalisation co-ordinators until 2025 and the strengthening of the coordinating role of the Swedish National Agency for Growth also support digital work, tools and services, as well as strategic cooperation between relevant stakeholders, thereby promoting regional growth (OECD, 2019b; Randall and Berlina, 2019 and references therein).

Nevertheless, information systems remain fragmented, as state agencies, regions and municipalities have generally developed their digital infrastructure independently, which limits the interoperability of IT systems and data sharing. To fully take advantage of the potential offered by digitalisation in the provision of public services, the government needs to strengthen its role in enhancing the infrastructure for data and information sharing and to provide adequate technical support to municipalities and regions in need. The governance framework needs to continue to move from the silo-based and uncoordinated path followed over the past decade to a whole-of-government approach with strong government leadership (OECD, 2019b).

Regulatory adaptation is also necessary to reap the potential benefits offered by technological advances, while adequately protecting users. In particular, legislation needs to strike the right balance between protecting privacy and permitting beneficial use of data for society as a whole and online services (Blix and Levay, 2018; OECD, 2018). The Committee on municipal capacity has recommended setting up a government inquiry to assess the regulatory changes required in order to ensure that the process of digital transformation occurs smoothly. The introduction of regulatory sandboxes could also allow firms in new technologies and new industries to test their products and business models without being subject to all existing legal requirements, as for example in the United Kingdom, Canada or Korea (OECD, 2018). The UK Financial Conduct Authority launched its Fintech regulatory sandbox in 2016 to encourage innovation in the field of financial technology. The sandbox provides the conditions for businesses to test innovative products and services in a controlled environment without incurring the regulatory consequences of pilot projects (Planes-Satorra and Paunov, 2019). In 2016, Canada introduced a sandbox allowing firms to register and/or obtain exemptions from securities laws requirements, under a faster and more flexible process than through a standard application, in order to test their products, services and applications throughout the Canadian market on a time limited basis (Canadian Securities Administrators, 2020). In 2019, the Korean government introduced regulatory sandboxes in areas such as FinTech, the medical sector, manufacturing, electronics, telecommunication, energy and mobility. In terms of digital technology, regulatory sandboxes have been approved for app-based platform technology, loT, big data, blockchain, artificial intelligence and virtual reality (OECD, 2020b). In a related vein, the recently-launched German "living labs for the energy transition" provide financing for testing innovative industrial technologies, with possibilities for regulatory learning. These projects are in many cases tailored to the conditions prevailing in a specific region (Box 5).

\section{Box 5. Living labs for energy transition in Germany}

In February 2019, Germany's Federal Ministry for Economic Affairs and Energy (BMWi) organised a competition for ideas for "living labs" for the energy transition (Reallabore der Energiewende) designed to help Germany transition to renewable energy. The living labs allow for regulatory learning and for large-scale industrial innovations to be tested outside of research labs. The competition centred on ideas for "sector coupling and hydrogen technologies", "large-scale energy storage in the electricity sector" and "energy-optimised neighbourhoods". The BMWi has set aside $€ 100$ million per year for 
living labs for energy transition between 2019 and 2022, but the living labs can receive funding for up to ten years. The BMWi announced the winners of the competition in July 2019 and the first project, "SmartQuart", was launched in January 2020. Led by the energy company E.ON, "SmartQuart" aims to optimise energy utilisation by connecting city quarters to "SmartQuart"-hubs that distribute energy efficiently between the connected quarters. To ensure that this system can be applied in a wider setting, the "SmartQuart" project is tried out in neighbourhoods in three different cities: high-density Essen, rural Bedburg and mixed-structure Kaisersesch.

Unlike regulatory sandboxes covering domains like FinTech or the medical sector, energy-transition living labs can be adapted to conditions that are specific to a certain region. For example, the "Westküste 100" project attempts to produce green hydrogen from offshore wind energy in western Schleswig-Holstein, a region with a lot of wind power and good geological storage conditions. In Brandenburg and Nordrhein-Westfalen, two Länder where coal plays an important economic role, the projects "RefLau" and "StoreToPower" projects seek to convert coal power plants into plants for green energy and heat storage that can still be used after coal is phased out. In fact, five out of the 20 regulatory living labs are in regions particularly affected by the phasing-out of coal power, and living labs in these regions will also receive an additional $€ 200$ million in funding.

Source: German Federal Ministry for Economic Affairs and Energy.

\section{Promoting regional growth and employment is essential}

Successful regions whose residents enjoy high levels of well-being rely on more than redistribution from other regions and support from central government. They also provide job opportunities and a dynamic environment. Raising labour productivity is key, as it historically accounts for between $45 \%$ and $85 \%$ of regional GDP differences (Enflo and Roses, 2015). In 2018, labour productivity ranged from nearly $120 \%$ of the national average in Stockholm to about $80 \%$ in Gotlands kommun (Figure 17). Norrbotten, even though a remote region, had the second highest productivity level, thanks to its mining activity, which has a high capital-to-output ratio. The two northernmost regions, Norrbotten and Västerbotten, have enjoyed among the largest increases in the employment rate since 2008 (Tillväxtverket, 2021). Large investments are currently taking place in Northern regions' mining and metal industries, notably to produce fossil-free steel and recycle metals, as well as car battery manufacturing. These investments will have a major positive impact on greening the economy (see Chapter 1 of the OECD Economic Survey of Sweden, 2021) and create great opportunities for further regional development. In December 2020, the government appointed a coordinator to link projects supporting business establishment and expansion in Norrbotten and Västerbotten, notably through skills supply, infrastructure and housing. Nevertheless, demographic developments remain challenging in these regions.

Regional inequality in productivity displays a high degree of inertia since the turn of the $21^{\text {st }}$ century (Figure 18). It also coincides with a high concentration of employment in the leading regions, especially Stockholm, which accounts for more than four in ten job creations over the period 2006-16. This share is relatively high by OECD standards, although lower than in most of the other Nordics (Figure 19). With increasing global competition, agglomeration effects in a knowledge-based economy, and relatively high wages, boosting employment in less central regions will also require increasing productivity and competitiveness. 
Figure 17. Productivity varies significantly across regions

GRDP per employee, 2018, Sweden $=100$, TL3 regions

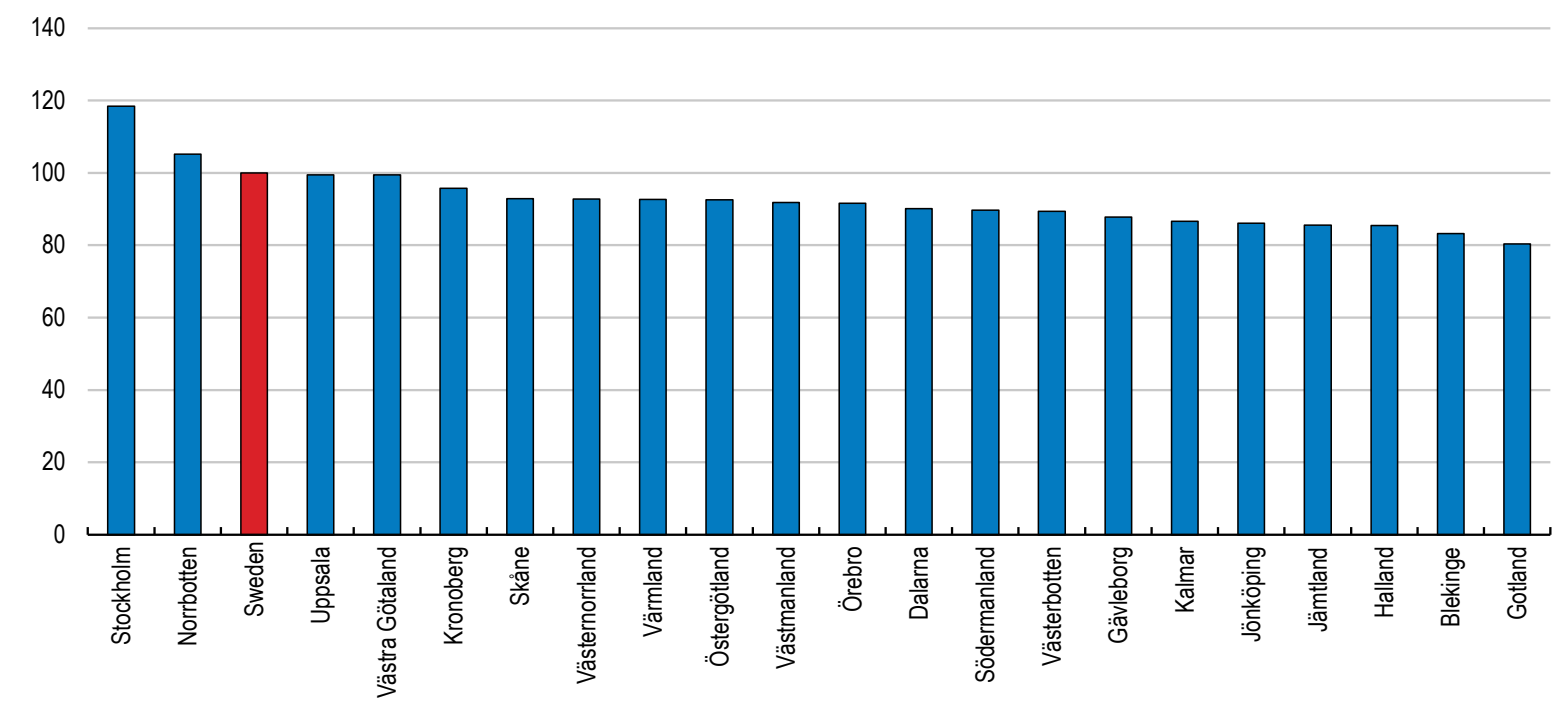

Source: Statistics Sweden.

Figure 18. Persistence of inequality in productivity levels within countries

Within country Spearman rank-correlation of regional productivity levels, 2000 and 2015

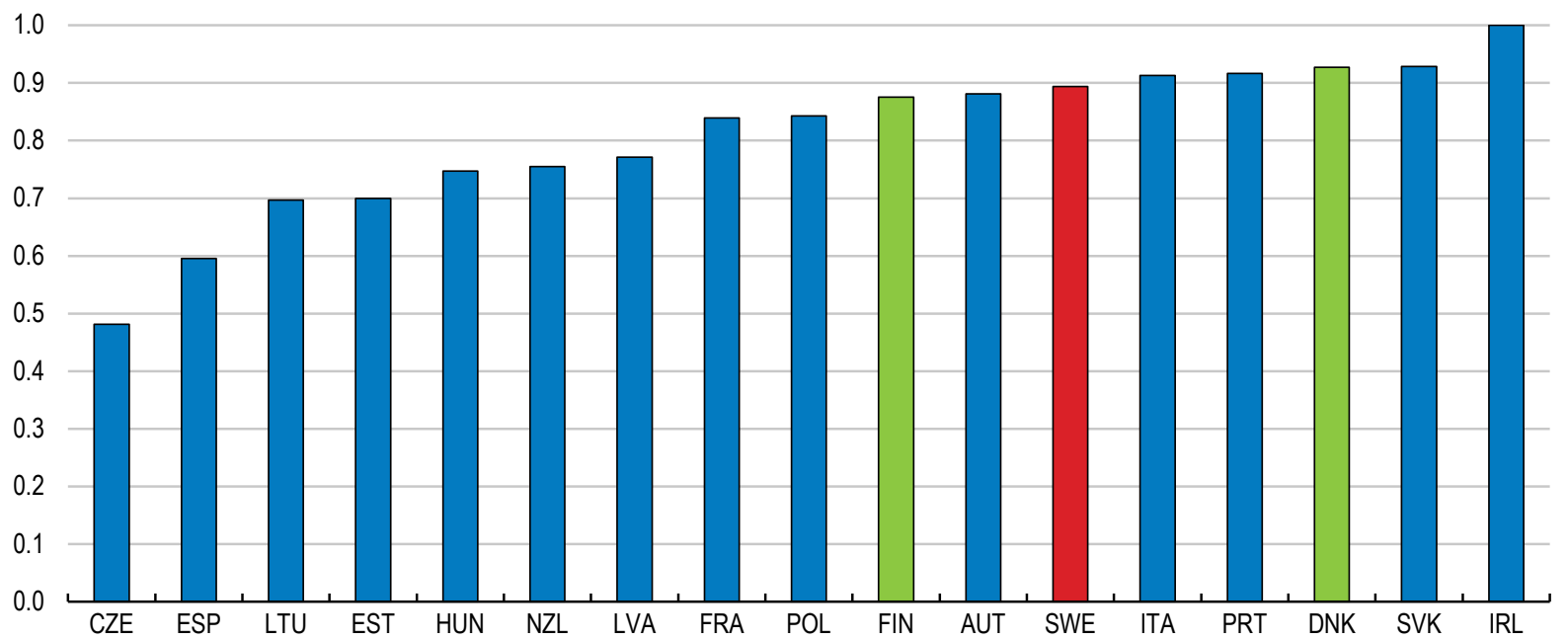

Notes: This graph shows the persistence of productivity differences across regions within a country. The higher the value, the higher the persistence in the ranking of regions by productivity level. Note that persistence in differences is not necessarily related to the overall magnitude of differences. Thus, even in countries that have a high degree of persistence in regional productivity levels, the actual differences across regions might be small.

Source: Calculations based on OECD Regional Statistics database.

Business dynamics are important for regional economies as new firms create employment, demand for other existing firms, and spur productivity through enhanced competition and innovation. However, in highproductivity and innovative sectors like high-technology manufacturing or knowledge-intensive services, firms are concentrated in the Stockholm region (André and Pak, 2021). In ICT services, $45 \%$ of firms are 
in the Stockholm region, while this share is $39 \%$ in professional services and $26 \%$ in high-technology manufacturing, which covers manufacture of ICT and pharmaceuticals products (based on operational units). Likewise, employment in these sectors is also concentrated in the Stockholm region.

\section{Figure 19. Job creation in capital regions}

Share of TL2 capital regions in net job creation and total employment

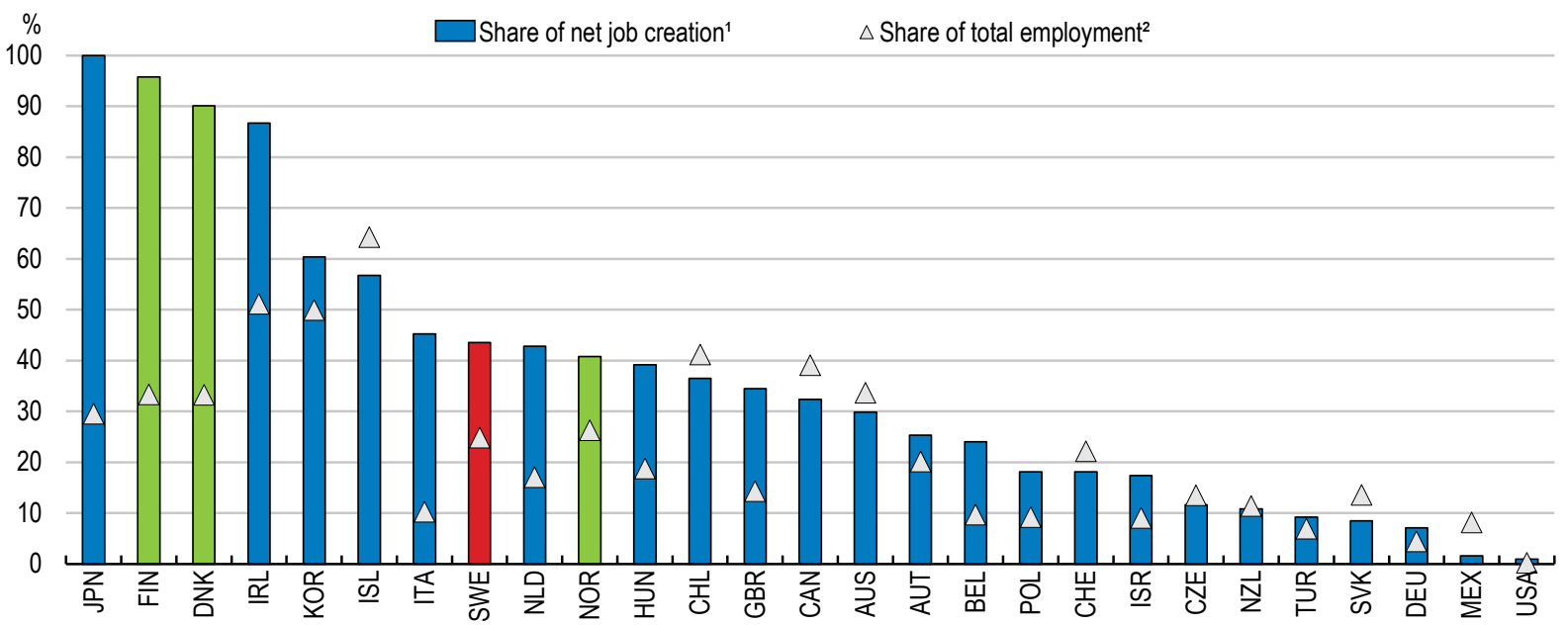

1. Net job creation in capital regions relative to nationwide job creation, 2006-16. Capital regions in Portugal, Spain and Slovenia lost jobs over the 2006-2016 period. Due to data availability, the values for Chile, Israel and Mexico cover the 2006-2014 period.

2. Total employment in capital regions relative to nationwide total employment, 2019 or latest.

Source: OECD (2018), Job Creation and Local Economic Development 2018: Preparing for the Future of Work.

Regional productivity is determined by global (e.g. general technological advances), national (e.g. policies and regulations) and local factors (e.g. geography, industry structure, local knowledge base, infrastructure). Both global and national factors may have different impacts across regions, according to their specificities. For example, the local knowledge base and availability of skilled workers influences technology adoption and national labour market regulations may have a different impact depending on the industry structure. Productivity determinants include in particular R\&D and technology, knowledge diffusion, business churn, human capital, institutions, policies and regulations (Tsvetkova et al., 2020). Although many of these factors are difficult to quantify, connectivity, knowledge intensive employment in manufacturing and services, R\&D and educational achievement are strongly associated to labour productivity across OECD regions (Box 6).

\section{Box 6. What characterises OECD's most productive regions?}

The literature has identified many factors associated with regional productivity (Tsvetkova et al., 2020), which are, however, often diffuse and difficult to quantify. This box examines the correlations between a variety of relevant indicators and labour productivity levels in a sample of up to 125 OECD regions in 17 countries (depending on data availability for different specifications). The analysis is carried out at the OECD TL2 level, which divides Sweden into 8 regions, rather than at the finer county level, to ensure wider indicator coverage across the sample.

The first column of Table 1 displays a relatively general panel equation (André and Pak, 2021), including statistically significant variables selected from a broader set of indicators. In subsequent columns, some variables are dropped to extend the sample, as data are missing for some regions. Alternative regressions with different variables and regions also serve as robustness checks. The results suggest the relevance of the following factors for regional productivity, even though they do not prove causality: 
- Connectivity: A higher density of motorways or railways is associated with higher productivity. The share of households with access to broadband is not significant in panel regressions. This likely reflects the high coverage reached in most of the regions in the sample. Nevertheless, a cross-section regression for 2018 clearly shows that regions with low coverage exhibit low productivity.

- Knowledge-intensive employment: although representing a small share of total employment on average (respectively around $1 \%$ and $5 \%$ ), high and mid-tech manufacturing is tightly linked to overall regional productivity, suggesting strong spillover effects. The relation between productivity and non-tech knowledge-intensive market services, which employ on average about a quarter of the workforce, is also robust.

- Research and education: higher R\&D expenditure is associated with higher productivity, even after controlling for the regional industrial structure and despite the potential disconnection between research and production sites. The share of the population with tertiary education also correlates with productivity, although the coefficients are less stable across specifications than for other variables, presumably reflecting complementarities with other factors.

- Investment: Higher investment rates should boost productivity through capital deepening. However, this effect could not be identified in the panel regressions. Conversely, high investment rates in construction and financial services are associated with somewhat lower regional productivity, suggesting that these sectors may divert resources from more productive industries.

\section{Table 1. Panel regressions for labour productivity}

\begin{tabular}{|c|c|c|c|c|c|}
\hline \multicolumn{6}{|l|}{ Dependent variable: $100^{*} \log \left(\right.$ labour productivity) ${ }^{1}$} \\
\hline Density of motorways (km per thousand $\mathrm{km}^{2}$ ) & $0.11^{* * *}$ & $0.14^{\star * *}$ & $0.16^{\star \star *}$ & $0.09^{\star * *}$ & $0.09^{\star * *}$ \\
\hline Density of railways ( $\mathrm{km}$ per thousand $\mathrm{km}^{2}$ ) & $0.08^{\star *}$ & .. & .. & .. & .. \\
\hline High-tech employment (\% of total employment) $)^{2}$ & $0.87^{* *}$ & $0.83^{* *}$ & $0.97^{\star * *}$ & $0.89^{* *}$ & $0.96^{* * *}$ \\
\hline Mid-tech employment (\% of total employment) ${ }^{2}$ & $1.26^{* * *}$ & $1.04^{* * *}$ & $0.98^{* * *}$ & $0.89^{* * *}$ & $0.84^{* * *}$ \\
\hline $\begin{array}{l}\text { Employment in non-high tech knowledge intensive market services } \\
\text { (\% of total employment })^{3}\end{array}$ & $0.60^{* * *}$ & $0.49^{* * *}$ & $0.50^{* * *}$ & $0.32^{* * *}$ & $0.44^{* * *}$ \\
\hline R\&D expenditure (\% of GDP) & $0.64^{\star *}$ & $0.56^{*}$ & .. & .. & .. \\
\hline Tertiary education (\% of population) & $0.87^{\star * *}$ & $0.27^{\star \star \star}$ & $0.13^{*}$ & .. & .. \\
\hline Investment in construction (\% of value added) & $-0.06^{* *}$ & $-0.07^{\star * *}$ & $-0.05^{\star *}$ & $-0.06^{* *}$ & .. \\
\hline Investment in financial services (\% of value added) & $-0.10^{* * *}$ & $-0.12^{* * *}$ & $-0.13^{* * *}$ & $-0.10^{* * *}$ & .. \\
\hline $\mathrm{R}^{2}$ (within) & 0.54 & 0.48 & 0.44 & 0.43 & 0.44 \\
\hline Total number of observations & 548 & 619 & 694 & 785 & 971 \\
\hline Period & $2008-17$ & $2008-17$ & $2008-17$ & $2008-17$ & $2008-18$ \\
\hline TL2 Regions & 70 & 81 & 81 & 95 & 125 \\
\hline Countries & $9(1)$ & $11(2)$ & $11(2)$ & $13(3)$ & $17(4)$ \\
\hline
\end{tabular}

1. The regressions include both region and time fixed effects. The coefficient are semi-elasticities (e.g. in the first column, an increase of one $\mathrm{km}$ per thousand $\mathrm{km}^{2}$ in the density of motorways increases the level of productivity by $\left.0.11 \%\right)$. (1) Czech Republic, Spain, Finland, Hungary, Italy, Norway, Portugal, Slovak Republic and Sweden are included; (2) Countries in (1) plus Austria and Poland; (3) Countries in (2) plus Denmark and Slovenia; (4) Countries in (3) plus Ireland, Lithuania, Switzerland and Turkey.

2. The classification of economic sectors into high-technology, medium high-technology, medium low-technology and low-technology industries is based on R\&D intensity at the European Community (NACE) 2-digit level.

3. Services are mainly aggregated into knowledge-intensive services on the basis of the share of tertiary educated persons at the NACE 2digit level.

Source: Authors' calculations. 
Across OECD countries, universities play a major role in regional growth. They stimulate the creation of knowledge networks, often support entrepreneurship and young firms, and help build and retain local skills. This generates business dynamism, capacity to absorb knowledge, and helps attract and retain skilled workers and companies, thereby raising productivity (Tsvetkova et al., 2020). Nordic experience confirms these findings. Andersson et al. (2004) show that labour productivity is higher in Swedish cities that have received larger university-based investments. Stein (2019) finds that the university cities of Troms $\varnothing$ and Umeå have played an important role in the development of Northern regions of Norway and Sweden, respectively. The potential trade-off between dispersing resources across regions and concentrating resources in excellence centres can be mitigated by the widening use of digital tools, which facilitate participation in global research networks.

The impact of universities on regional growth, along with their role in providing a skilled workforce, depends on their ability to translate research into innovation, through their integration in entrepreneurship networks, and to reinforce regional comparative advantages. Research and education fields matching local industry and service specialisation are particularly relevant to foster innovation and retain graduates, who are increasingly leaving their place of education after completing their studies, especially if it lies outside the larger metropolitan regions (Rehak and Eriksson, 2019). For example, more than $70 \%$ of Umeå university students left after graduating in 2013 . Among these $70 \%$, nearly $27 \%$ were local students (Eklund et al., 2019). Student migration is partly due to a lack of job and career opportunities in some regions and a high wage premium for bigger cities, especially Stockholm (Eliasson and Westerlund, 2019).

There is scope for strengthening the role of Swedish universities in innovation. The Research and Innovation Bills of 2008 and 2012 introduced a number of policy initiatives aimed at strengthening the performance of the Swedish science, technology and innovation system. They were followed by further initiatives in the 2016 Research Bill and the 2020 Research and Innovation Bill. In particular, policies strengthened the position of research institutes and their role in linking research and innovation, and aimed at improving international competitiveness and finding sustainable solutions to global challenges by enhancing interactions between various stakeholders. However, these policies have been only been partially successful in bolstering the translation of research into innovation (OECD, 2016b).

A recent government enquiry pointed to inefficient support for innovation in higher education, which results in disparate outcomes across institutions (Swedish government, 2020c). This calls for deepening the involvement of tertiary education institutions in local innovation networks, in particular through enhanced incentives and support mechanisms. The December 2020 Research and innovation bill (Swedish government, 2020d) increases funding for research and innovation significantly over the period 2021-24, in particular to grant tertiary education institutions more freedom to develop their strategic priorities. It also facilitates the commercialisation of research and announces a new strategy to strengthen synergies with EU research programmes.

Korean technoparks offer an example of successful policy-led cooperation between a wide range of stakeholders to foster regional innovation and growth (Box 7). Regional clusters in the Netherlands have also boosted innovation and increased the resilience of the economy to industry-specific external shocks (Box 8).

\section{Box 7. Technoparks in Korea}

Korea faces increasing economic concentration in the Greater Seoul area, causing regional inequality. In response, the government has introduced various policy measures, among which Technopark, a science and technology cluster project started in 1998 to overcome regional imbalances and support regional development. It is designed to support the innovation and growth of local SMEs by gathering regional innovation capabilities from local industries, universities and research institutes, with government support. Technopark has since grown into a core project supporting regional industrial 
development and local SMEs. It plays a key role in mobilising regional innovation (OECD, 2012). Six technoparks were designated in 1998, and their number increased to 19 by 2021 . The government has invested KRW 410 billion (about USD 370 million) in technoparks from 1998 to 2018, in the form of grants. There were a total of 2100 Technopark companies with around 30000 employees in 2019, recording sales of KRW 13 trillion (about USD 11.4 billion). The rapid growth of technoparks in Korea was driven by strong cooperation between the central government and municipalities, close links with universities and companies, which fostered competitive regional industries. In addition, institutional and policy support for Technopark, including funding, manpower and tax benefits, contributed to the growth of technoparks and positive spillovers to local economic development (Rhee, 2021).

Source: The Korea Technopark Association.

\section{Box 8. Regional clusters in the Netherlands}

Dutch regional policy, together with national development strategies, supports the development of hightech clusters in areas where the country enjoys comparative advantages, to foster economic growth, create jobs and boost competitiveness. Regional clusters help creating prosperity across the country, directly and through spillovers to other activities. In addition, the variety of clusters, covering a broad range of economic activities, creates diversity, which enhances the country's innovative capabilities and resilience to industry-specific external shocks.

The cluster development strategy focusses on public-private partnerships to foster investment from a wide range of actors, including companies, government and knowledge institutes. R\&D is supported through tax credits, incentives for government bodies to fund selected activities and connections to global innovation networks.

The main clusters include: Mainports, building on connectivity around Amsterdam-Schiphol airport and Rotterdam Seaport; Brainport, a high-tech cluster stemming from industries related to Philips in Eindhoven; Greenports, an array of agriculture and horticulture clusters; Energy Valley, a cluster of companies producing energy from gas (including biogas) and wind in the province of Groningen; Food Valley, a well-integrated network of international food companies, research institutes and universities in the province of Gelderland; Health Valley, located in the same province, fostering cooperation between the biomedical and healthcare sectors.

Source: OECD (2014), OECD Territorial Reviews: Netherlands 2014, OECD Publishing, Paris; OECD (2018), Productivity and Jobs in a Globalised World: (How) Can All Regions Benefit?, OECD Publishing, Paris.

While reinforcing regional centres is essential, addressing the rising income and opportunity divide within regions is equally important. Better coordination between different levels of government, state agencies and other stakeholders to increase connectivity between regional centres and surrounding areas could boost regional growth and mitigate urban-rural inequality. An environmentally sustainable transport infrastructure is key to broadening functional labour markets and improving matching between jobseekers and employers. It also improves access to markets. Well-connected areas are bound to attract or retain more inhabitants and businesses. Digitalisation also increases connectivity and the planned expansion of broadband will provide further opportunities. Telework, at least on a part-time basis, could improve opportunities for people living in remote areas, even though teleworking possibilities are unequal across regions (Figure 20). Further developing distance education would facilitate access both to conventional education and to re-training and re-skilling, especially in remote areas. 
Efforts to build urban-rural linkages have been stepped up in recent years, in particular through promoting greater inter-municipal co-operation in public service delivery and regional development strategies prioritising planning based on functional labour market areas. Multi-level governance capacity has increased, with a strengthened role for regions and a move toward stronger co-ordination of regional policy. However, cooperation between government entities, including state agencies, and with other stakeholders, would need to be reinforced to develop a coherent vision for rural areas, with clear articulation to national policy in areas like education and health services, spatial planning and transport (OECD, 2017a; Tillväxtverket, 2019).

Housing shortages may be an obstacle to regional growth and increase income inequality by preventing labour mobility, especially for low-income workers. The number of jobs amenable to telework is also far greater in urban than in remote areas. While housing shortages are most acute in big cities and particularly Stockholm, 212 out of 290 municipalities reported shortages in 2020 (Boverket, 2020). Recent OECD estimates suggest that $1 \%$ higher house prices reduce regional migration by nearly $1 \%$ (Cavalleri et al., 2021). Factors affecting the availability and affordability of housing include property taxation favouring homeownership, tight rental regulations preventing an efficient use of the existing housing stock, inefficient land-use planning, low incentives for municipalities to encourage development holding back housing supply and a lack of competition in construction pushing up construction costs (OECD Economic Survey of Sweden, 2019).

\section{Figure 20. Telework possibilities are uneven across regions}

Share of jobs that can potentially be performed remotely (\%), 2018, NUTS-1 or NUTS-2 (TL2) regions, selected $\mathrm{OECD}$ and EU

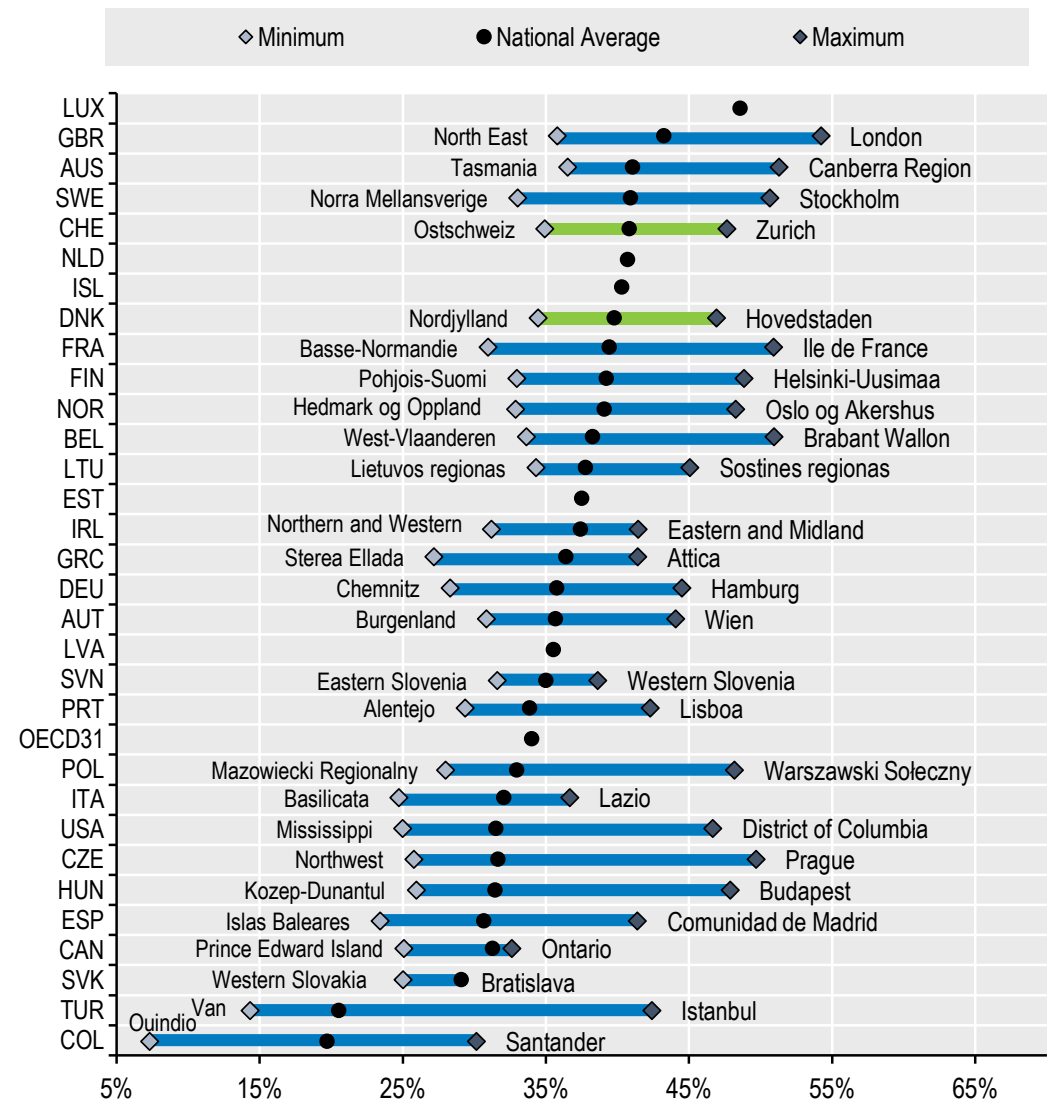

Source: Adapted from OECD (2020), "Capacity for remote working can affect lockdown costs differently across places", OECD Policy Responses to Coronavirus (COVID-19), and OECD (2020), OECD Regions and Cities at a Glance 2020, OECD Publishing, Paris. 


\section{Recommendations to contain the rise in regional inequality}

Key recommendations in bold

\begin{tabular}{|c|c|}
\hline MAIN FINDINGS & RECOMMENDATIONS \\
\hline \multicolumn{2}{|c|}{ Upgrade the sub-national government fiscal framework } \\
\hline $\begin{array}{l}\text { The share of earmarked grants has increased over recent years. These } \\
\text { grants are in some cases narrowly targeted and short-term, which makes } \\
\text { efficient use challenging. }\end{array}$ & $\begin{array}{l}\text { Limit the use of earmarked grants to strategic areas. } \\
\text { Avoid excessively narrowly targeted and short-term grants. }\end{array}$ \\
\hline $\begin{array}{l}\text { The fiscal equalisation system is complex and generally perceived as } \\
\text { lacking transparency. A commission reviews the system every five or six } \\
\text { years, but monitoring and discussion between reviews is limited. }\end{array}$ & $\begin{array}{l}\text { Simplify the fiscal equalisation system and/or increase } \\
\text { transparency. } \\
\text { Introduce monitoring on an ongoing basis to facilitate } \\
\text { adjustments. }\end{array}$ \\
\hline \multicolumn{2}{|c|}{ Enhance public service provision efficiency } \\
\hline $\begin{array}{l}\text { Digital tools offer potential for providing better services and raising } \\
\text { efficiency. User demand looks strong, notably in health and education. } \\
\text { Digital capabilities vary widely across local authorities. }\end{array}$ & $\begin{array}{l}\text { Develop further on-line public services delivery. } \\
\text { Enhance the public infrastructure for data and information } \\
\text { sharing. }\end{array}$ \\
\hline $\begin{array}{l}\text { Inter-municipal cooperation to provide public services more efficiently } \\
\text { has increased, but strategic vision remains insufficient. }\end{array}$ & $\begin{array}{l}\text { Strengthen regional strategic steering, consultation and dialogue with } \\
\text { municipalities and rigorous project evaluation, to promote more } \\
\text { strategic inter-municipal cooperation. }\end{array}$ \\
\hline $\begin{array}{l}\text { Municipalities tend to face difficulties in meeting standards set by the } \\
\text { central government in some areas, especially personal assistance and } \\
\text { integration of immigrants. }\end{array}$ & $\begin{array}{l}\text { Shift the financing of personal assistance to the national level. Extend } \\
\text { the financing of immigrant integration beyond the first two years. }\end{array}$ \\
\hline $\begin{array}{l}\text { Access to basic public services, including police and employment } \\
\text { services, is limited in some remote areas. Digital access is only a partial } \\
\text { substitute. }\end{array}$ & $\begin{array}{l}\text { Set up a government enquiry to investigate the ways to improve access } \\
\text { to basic services in remote areas in a cost effective way. }\end{array}$ \\
\hline \multicolumn{2}{|c|}{ Support regional growth } \\
\hline $\begin{array}{l}\text { Universities contribute to a varying degree to regional development by } \\
\text { fostering and helping retain local talent and by strengthening } \\
\text { competitiveness and business dynamism through participation in local } \\
\text { research and innovation networks. }\end{array}$ & $\begin{array}{l}\text { Strengthen incentives and support to raise the contribution of } \\
\text { universities to regional knowledge and innovation. }\end{array}$ \\
\hline $\begin{array}{l}\text { Strategic spatial plans and coordination between government entities } \\
\text { and with other stakeholders are insufficiently developed. Coherent } \\
\text { development plans could increase job and business opportunities within } \\
\text { functional labour market areas. }\end{array}$ & $\begin{array}{l}\text { Strengthen multi-level governance, including coordination of } \\
\text { sector policies and cooperation between government entities and } \\
\text { other stakeholders, to enhance strategic cooperation for regional } \\
\text { development. }\end{array}$ \\
\hline $\begin{array}{l}\text { Municipalities offer digital training in local centres, but limited to basic } \\
\text { use of digital devices. }\end{array}$ & $\begin{array}{l}\text { Upgrade and increase the range of proposed digital training in municipal } \\
\text { centres. }\end{array}$ \\
\hline
\end{tabular}




\section{References}

Andersson, R., J.M. Quigley and M. Wilhelmson (2004), "University decentralization as regional policy: the Swedish experiment", Journal of Economic Geography, 4(4), 371-388.

André, C. and M. Pak (2021), "Regional differences in productivity in Sweden: insights from OECD regions", OECD Economics Department Working Papers, No. 1688, OECD Publishing, Paris.

André, C., J. Pareliussen and H. Hwang (2020), "Swedish school results, student background, competition and efficiency", Educational Studies Moscow, No. 3.

Andrews, D. and F. Cingano (2014), "Public policy and resource allocation: evidence from firms in OECD countries", Economic Policy, Vol. 29.

Arbetsförmedlingen (2019a), "Var finns jobben? Bedömning för 2019 och på fem års sikt" (Where are the jobs? Assessment for 2019 and at a five year horizon), Swedish Public Employment Service, Stockholm.

Arbetsförmedlingen (2019b), "Sveriges framtida sysselsättning. Vad behövs för att undvika ökad försöriningsbörda?" (Sweden's future employment. What is needed to avoid an increased dependency ratio?), Swedish Public Employment Service, Stockholm.

Arnold, J.M., B. Brys, C. Heady, Å. Johansson, C. Schwellnus and L. Vartia (2011), “Tax policy for economic recovery and growth", The Economic Journal, 121: F59-F80.

Bergdahl, N. and J. Nouri (2020), "Covid-19 and crisis-prompted distance education in Sweden", Technology, Knowledge and Learning.

Bisciari, P., D. Essers and E. Vincent (2020), "Does the EU convergence machine still work?", NBB Economic Review, June, National Bank of Belgium, Brussels.

Blix, M. and A. Morin (2020), "Mer pengar löser inte kommunkrisen efter corona" (More money does not solve the crisis for the municipalities after the corona crisis), Ekonomisk Debatt, Nr.7, årgång 48.

Blix, M. and J. Jeansson (2018), "Telemedicine and the welfare State: the Swedish experience", Research Institute of Industrial Economics Working Paper Series, No. 1238, Stockholm.

Blix, M. and C. Levay (2018), Digitalization and Health Care - A report to the Swedish Government's Expert Group on Public Economics, The Expert Group on Public Economics 2018:6, Stockholm.

Blix, M. (2015), The Economy and Digitalization - Opportunities and Challenges, Svenskt Näringsliv, Stockholm.

Blöchliger, H., D. Bartolini and S. Stossberg (2016), "Does fiscal decentralisation foster regional convergence?", OECD Economic Policy Papers, No. 17, OECD Publishing, Paris.

Boverket (2020), “212 av 290 kommuner har fortfarande brist på bostäder" (212 out of 290 municipalities still face a housing shortage), Karlskrona.

Brys, B. et al. (2021), Effective Taxation of Residential Property, OECD Publishing, Paris, forthcoming.

Canadian Securities Administrators (2020), "CSA Regulatory Sandbox", accessed on 2 March 2020.

Carlsson, M., I. Häkkinen Skans and O. Nordström Skans (2019), "Wage Flexibility in a Unionized Economy with Stable Wage Dispersion", IZA Discussion Papers, No. 12093, Institute of Labor Economics (IZA), Bonn.

Cavalleri, M.C., N. Luu and O. Causa (2021), "Migration, housing and regional disparities: a gravity model of cross-regional migration with an application to selected OECD countries", OECD Economics Department Working Papers, OECD Publishing, Paris, forthcoming.

Cournède, B., J.-M. Fournier and P. Hoeller (2018), "Public Finance Structure and Inclusive Growth", OECD Economic Policy Paper, No. 25, OECD Publishing, Paris.

de Mello, L. and T. Ter-Minassian (2020), "Digitalisation challenges and opportunities for subnational governments", OECD Working Papers on Fiscal Federalism, No. 31. 
Dougherty, S. and K. Forman (2021), "Evaluating fiscal equalisation: finding the right balance", OECD Working Papers on Fiscal Federalism, No. 36, OECD Publishing, Paris.

Dougherty, S., M. Harding and A. Reschovsky (2019), "Twenty years of tax autonomy across levels of government: Measurement and applications", OECD Working Papers on Fiscal Federalism, No. 29.

Eklund, J., R. Eriksson and J. Lundberg (2019), "Ska jag stanna eller flytta? En analys av nyutexaminerade studenters flyttmönster" (Should I stay or move? An analysis of newly graduated student migration patterns), University of Umeå, Cerum report, No. 55.

Eliasson, K. and O. Westerlund (2019), "Graduate migration, self-selection and urban wage premiums across the regional hierarchy", Swedish Agency for Growth Policy Analysis Working Papers, No. 2019:03.

Enflo, K. (2016), "Regional ojämlikhet i Sverige. En historisk analys" (Regional inequality in Sweden. A historical analysis), SNS Analys, No. 33, SNS, Stockholm.

Enflo, K. and J. Rosés (2015), "Coping with regional inequality in Sweden: structural change, migrations and policy, 1860-2000", Economic History Review, 68(1), 191-217.

Forman, K., S. Dougherty and H. Blöchliger (2020), "Synthesising good practices in fiscal federalism: Key recommendations from 15 years of country surveys", OECD Economic Policy Papers, No. 28, OECD Publishing, Paris.

Gbohoui, W., W. R. Lam and V. Lledo (2019), “The Great Divide: regional inequality and fiscal policy", IMF Working Papers 2019/088, International Monetary Fund, Washington DC.

Ministry of Enterprise and Innovation (2015), Sweden's National Strategy for Sustainable Regional Growth and Attractiveness 2015-2020, Stockholm.

New Zealand Department of Internal Affairs (2021), "Better Local Government", accessed on 5 April 2021. ECO/EDR(2021)3/ANN1

OECD (2021), Mining Regions and Cities Case of Västerbotten and Norrbotten, Sweden, OECD Rural Studies, OECD Publishing, Paris.

OECD (2020a), The Circular Economy in Umeå, Sweden, OECD Urban Studies, OECD Publishing, Paris.

OECD (2020b), OECD Economic Surveys: Korea 2020, OECD Publishing, Paris.

OECD (2019a), Negotiating Our Way Up: Collective Bargaining in a Changing World of Work, OECD Publishing, Paris.

OECD (2019b), Digital Government Review of Sweden: Towards a Data-driven Public Sector, OECD Digital Government Studies, OECD Publishing, Paris.

OECD (2018), OECD Reviews of Digital Transformation: Going Digital in Sweden, OECD Publishing, Paris.

OECD (2017a), OECD Territorial Reviews: Sweden 2017: Monitoring Progress in Multi-level Governance and Rural Policy, OECD Publishing, Paris.

OECD (2017b), Multi-level Governance Reforms: Overview of OECD Country Experiences, OECD Multilevel Governance Studies, OECD Publishing, Paris.

OECD (2016a), Working Together: Skills and Labour Market Integration of Immigrants and their Children in Sweden, OECD Publishing, Paris.

OECD (2016b), OECD Reviews of Innovation Policy: Sweden 2016, OECD Publishing, Paris.

OECD (2015a), The Metropolitan Century: Understanding Urbanisation and its Consequences, OECD Publishing, Paris.

OECD (2015b), Employment and Skills Strategies in Sweden, OECD Reviews on Local Job Creation, OECD Publishing, Paris. 
OECD (2012), Industrial Policy and Territorial Development: Lessons from Korea, Development Centre Studies, OECD Publishing, Paris.

OECD/KIPF (2016), Fiscal Federalism 2016: Making Decentralisation Work, OECD Publishing, Paris.

Oliveira Hashiguchi, T. (2020), "Bringing health care to the patient: An overview of the use of telemedicine in OECD countries", OECD Health Working Papers, No. 116, OECD Publishing, Paris.

Pareliussen, J., C. André and H. Hwang (2019), "Improving school results and equity in compulsory education in Sweden", OECD Economics Department Working Papers, No. 1587, OECD Publishing, Paris.

Planes-Satorra, S. and C. Paunov (2019), "The digital innovation policy landscape in 2019", OECD Science, Technology and Industry Policy Papers, No. 71, OECD Publishing, Paris.

Randall, L. and A. Berlina (2019), "Governing the digital transition in Nordic regions: the human element", Nordregio report 2019:4, Stockholm.

Rehak, S. and R. Eriksson (2019), "Migration of university graduates and structural aspects of regional higher education", European Planning Studies, 28(10), 1941-1959.

Rhee, J. (2021), "Korea TechnoPark: Evolving Integrated Business Platform", forthcoming.

SKR (2020a), Remissvar beträffande Kommunutredningen (SOU 2020:8) (Response to the enquiry on municipalities, SOU 2020:8), Sveriges Kommuner och Regioner, Stockholm.

Sorbe, S., P. Gal and V. Millot (2018), "Can productivity still grow in service-based economies? Literature overview and preliminary evidence from OECD countries", OECD Economics Department Working Papers, No. 1531, OECD Publishing, Paris.

Stein, J. (2019), "The striking similarities between Northern Norway and Northern Sweden" Arctic Review on Law and Politics, 10, 79-102.

Sturup, J. et al. (2019), "Increased gun violence among young males in Sweden: a descriptive national survey and international comparison", European Journal on Criminal Policy and Research, 25, 365378.

Swedish Government (2021), "Nationell strategi för hållbar regional utveckling i hela landet 2021-2030" (National strategy for sustainable regional development throughout the country 2021-2030), Regeringens skrivelse, 2020/21:133, Stockholm.

Swedish Government (2020a), "En gemensam angelägenhet, Betänkande av Jämlikhetskommissionen" (A common concern. Report of the Commission on Equality), SOU 2020:46, Stockholm.

Swedish Government (2020b), "Starkare kommuner - med kapacitet att klara välfärdsuppdraget, Slutbetänkande av Kommunutredningen" (Stronger municipalities - with the capacity to fulfil their welfare missions, Final report of the Municipal Inquiry, SOU 2020:8, Stockholm.

Swedish Government (2020c), "Innovation som drivkraft - från forskning till nytta" (Innovation as a driving force - from research to benefit), SOU 2020:59, Stockholm.

Swedish Government (2019a), “Långtidsutredningen 2019” (Long-term survey 2019), SOU 2019:65, Stockholm.

Swedish Government (2019b), "Lagrådsremiss, Ändringar i kostnadsutjämningen för kommuner och landsting" (Draft bill submitted to the Council on Legislation, Changes in cost equalisation for municipalities and county councils), 29 August, Stockholm.

Swedish Government (2018), "Lite mer lika, Översyn av kostnadsutjämningen för kommuner och landsting, Betänkande av Kostnadsutjämningsutredningen" (A little more similar, Review of cost equalization for municipalities and county councils, Report of the Cost Equalization Inquiry), SOU 2018:74, Stockholm.

Tillväxtverket (2021), "Tillstånd och trender för regional tillväxt 2020" (Situation and trends for regional growth 2020), Swedish Agency for Economic and Regional Growth, Stockholm. 
Tillväxtverket (2020), "Landsbygders kompetensförsörining - redovisning till regeringen" (Skills supply in rural areas - report to the government), Swedish Agency for Economic and Regional Growth, Stockholm.

Tillväxtverket (2019), "Regionalt tillväxtarbete efter 2020 - Regionernas framtida prioriteringar" (Regional growth work after 2020 - The regions' future priorities), Rapport 0298, Swedish Agency for Economic and Regional Growth, Stockholm.

Tillväxtverket (2018), "Tillstånd och trender för regional tillväxt 2018" (Conditions and trends for regional growth 2018), Rapport 0256, Swedish Agency for Economic and Regional Growth, Stockholm.

Tsvetkova, A. et al. (2020), "The spatial dimension of productivity: connecting the dots across industries, firms and places", OECD Regional Development Working Papers, No. 2020/01, OECD Publishing, Paris. 